\title{
Functional neuropeptidomics in invertebrates
}

Wouter De Haes", Elien Van Sinay", Giel Detienne, Liesbet Temmerman, Liliane Schoofs, Kurt Boonen*

${ }^{\#}$ Equally contributing authors

Functional Genomics and Proteomics, Department of Biology, University of Leuven (KU Leuven), Naamsestraat 59, 3000 Leuven, Belgium

*Corresponding author: Naamsestraat 59, bus 2456, 3000 Leuven, Belgium. Tel.: +32 16324260; fax: +32 16323902. E-mail address: Kurt.Boonen@bio.kuleuven.be

\begin{abstract}
Neuropeptides are key messengers in almost all physiological processes. They originate from larger precursors and are extensively processed to become bioactive. Neuropeptidomics aims to comprehensively identify the collection of neuropeptides in an organism, organ, tissue or cell. The neuropeptidome of several invertebrates is thoroughly explored since they are important model organisms (and models for human diseases), disease vectors and pest species. The charting of the neuropeptidome is the first step towards understanding peptidergic signaling. This review will first discuss the latest developments in exploring the neuropeptidome. The physiological roles and modes of action of neuropeptides can be explored in two ways, which are largely orthogonal and therefore complementary. The first way consists of inferring the functions of neuropeptides by a forward approach where neuropeptide profiles are compared under different physiological conditions. Second is the reverse approach were neuropeptide collections are used to screen for receptor-binding. This is followed by localization studies and functional tests. This review will focus on how these different functional screening methods contributed to the field of invertebrate neuropeptidomics and expanded our knowledge of peptidergic signaling.
\end{abstract}




\section{Keywords}

Mass spectrometry, GPCR, endocrinology, peptidomics, neuropeptides

\section{Abbreviations}

CE

Capillary electrophoresis

$\mathrm{CHO}$

Chinese hamster ovary

CNS

Central nervous system

DiLeu

$\mathrm{N}, \mathrm{N}$-dimethyl leucine

dsRed

Red fluorescent protein

GFP

Green fluorescent protein

GPCRs

G-protein coupled receptors

HEK

Human embryonic kidney

IMS

Imaging mass spectrometry

iTRAQ

Isobaric tags for relative and absolute quantification

LC

Liquid chromatography

MALDI-TOF

Matrix-assisted laser desorption/ionization time-of-flight

MS

Mass spectrometry

MS/MS

Tandem mass spectrometry

PCR

Polymerase chain reaction

RNAi

RNA interference

RP-HPLC

Reversed-phase high-performance liquid chromatography

RTKs

Receptor tyrosine kinases

SILAC

Stable isotope labeling with amino acids in cell cultures

TMAB

4-trimethylammoniumbutyryl

TMT

Tandem mass tags 


\section{Introduction}

There are several classes of endogenous bioactive peptides, for example antimicrobial (or antifungal) peptides that are active in host-defense [1,2], but the most common class consists of (neuro-)endocrine signaling molecules. Peptidergic signaling is crucial for all multicellular life, as correct responses to changing environments or internal stressors require communication between different specialized cells and tissues. While peptidergic signals may originate from non-neuronal tissues (e.g. insulin), many endogenous peptides are neuronal in nature, and these so-called neuropeptides may act as neurohormones, neurotransmitters or neuromodulators [3].

Neuropeptides are directly encoded in the genome and are initially produced as large precursor molecules, called preprohormones. All have an amino-terminal signal peptide which is immediately removed upon arrival in the endoplasmic reticulum [4]. The remaining prohormone is commonly cleaved at mono- or dibasic sites by endopeptidases within the Golgi apparatus and immature secretory granules, to release the fully processed peptides $[5,6]$. In addition, many neuropeptides require further post-translational processing for their biological activity and stability, such as removal of the C-terminal basic residues, amidation, glycosylation, acetylation, sulfation or phosphorylation (Fig. 1). In their mature bioactive form, peptide length ranges from as short as 3 (e.g. thyrotropin-releasing hormone) to more than 100 amino acids [7]. Signaling peptides exert their function by binding to receptors, resulting in the activation of intracellular signaling pathways and a physiological response $[8,9]$. Therefore, signaling peptides, their receptors and downstream effectors are functional units of peptidergic signaling and require to be studied all in order to understand their physiological functions [10].

Peptidergic signaling has been extensively studied in a multitude of invertebrate species because of their economic importance as pest species (e.g. locusts such as Schistocerca gregaria or Locusta migratoria and the flour beetle Tribolium castaneum), disease vectors (e.g. the tsetse fly Glossina morsitans) or as beneficial pollinators (e.g. the honey bee Apis mellifera). Furthermore, several invertebrate models such as the nematode Caenorhabditis elegans or the fruit fly Drosophila melanogaster lend themselves well as model organisms for the study of endocrine signaling, due to their relative simplicity and the existence of extensive genetic toolsets. C. elegans and D. melanogaster are used as models for neurodegenerative diseases, which have important neuropeptidergic components $[11,12]$. In these invertebrates, 
neuropeptidergic signaling has also been linked to various evolutionarily conserved developmental, physiological and behavioral processes such as learning and memory $[13,14]$, defecation [15], locomotion [16-18], longevity [19,20], reproduction [21,22] and others (as further reviewed by Taghert and Nitabach [23] and by Caers et al. [9]).

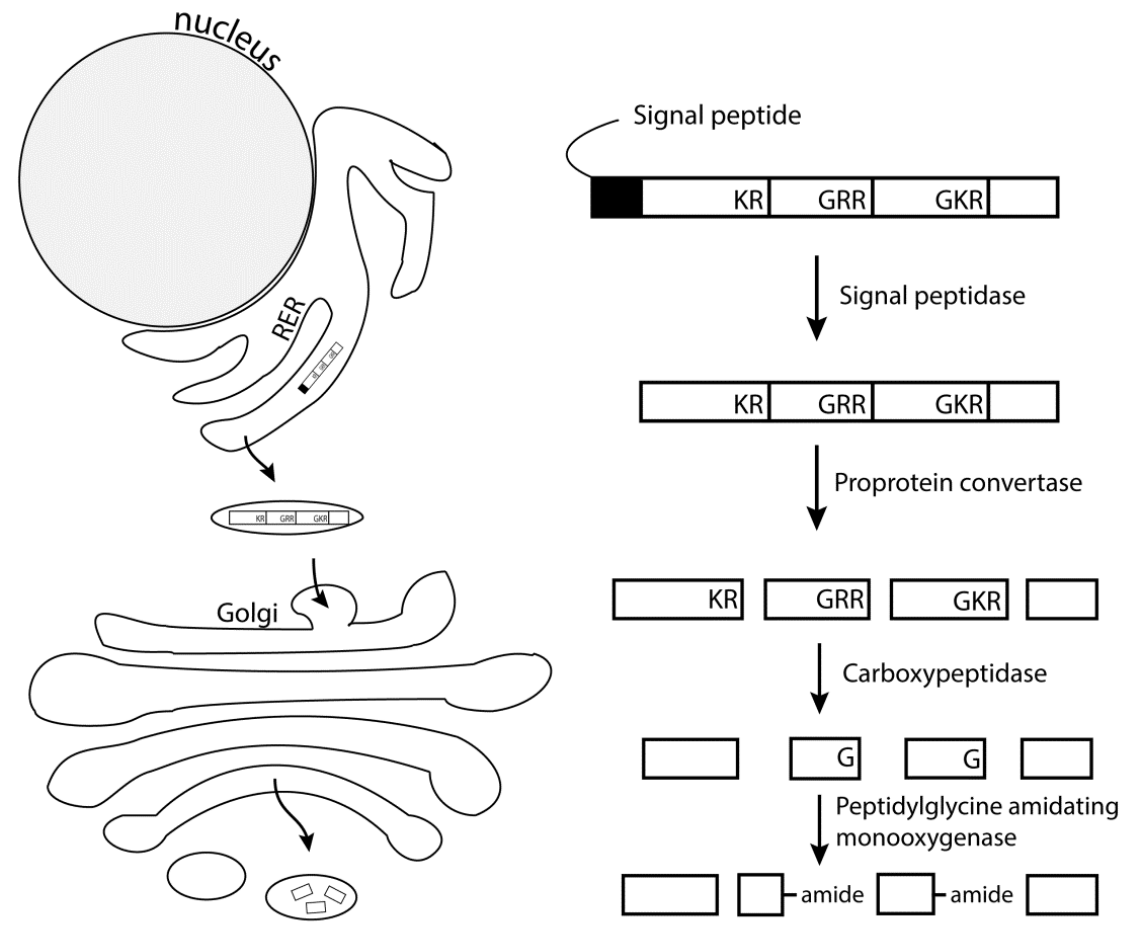

Fig. 1: Schematic overview of bioactive peptide processing in the secretory pathway. Peptides are first produced as preprohormones, which possess an amino-terminal signal peptide. This signal peptide is removed by a signal peptidase upon arrival in the rough endoplasmic reticulum (RER), which enters the peptide into the secretory pathway. The remaining prohormone is sent to the Golgi complex and is commonly cleaved at mono- or dibasic sites (often KR) by proprotein convertases after which the mono- or dibasic site is removed by carboxypeptidases. In addition, many endogenous peptides are further processed, e.g. C-terminal glycines provide the amine groups for C-terminal amino acids of amidated peptides (pictured here), and peptides can be glycosylated, pyroglutamated, acetylated, sulfated or phosphorylated. In their fully processed bioactive form, peptides are gathered in secretory granules and released after stimulation [4-7].

The large-scale study of the function, expression and structure of endogenous peptides has been termed peptidomics, and can be considered a specialized off-shoot of the domain of proteomics and functional genomics [24-26]. Neuropeptidomics is the subfield of peptidomics that is focused on neuropeptides. Several techniques native to the domain of proteomics have been adapted for use in peptidomics studies (as reviewed by Boonen et al. 
[27]) and applying these techniques has led to significant advances in the study of bioactive peptides.

This review will discuss the recent developments in charting the neuropeptidome of invertebrates, the first step to unravel peptidergic signaling pathways. We will further discuss how peptidomics techniques have contributed to knowledge of peptidergic signaling in invertebrates, from receptor binding to physiological functions. Two main screening approaches will be illustrated, a forward approach where peptide expression profiles are correlated with physiological conditions, and a reverse approach, where receptors (usually Gprotein coupled receptors or GPCRs) are screened with neuropeptide collections (from peptidomic studies) for peptide binding.

\section{Recent developments related to peptidomics technology}

Peptidomics aims to identify the endogenous peptide complement in cells, organs, tissues and organisms. The functional forms of neuropeptides can be hard to predict from the genome because of their extensive processing (similar difficulties occur with splicing and protein modification in proteomics) and physical detection methods are an essential support to genomic predictions. The field of peptidomics, focusing on peptide detection, has been around for almost 15 years and is predominantly based on mass spectrometry coupled to chromatographic techniques (LC and CE [28]) and on bioinformatics. We can refer to several reviews on this topic [27,29,30] and will only discuss the major improvements of the last years that specifically pertain peptidomics. Peptidomics hardware is identical to efficient shotgun proteomics hardware and has lately benefitted considerably from the introduction of improved mass spectrometers like Orbitraps [31], UPLC (ultra performance liquid chromatography) and the implementation of additional peptide fragmentation methods next to CID (collision induced dissociation), such as ETD (electron transfer dissociation) [32,33]. There are several important differences between peptidomics and proteomics, ranging from sample preparation to analysis strategies. Peptidomics analyses endogenous peptides, contrary to the tryptic peptides from bottom-up proteomics. Both proteomics and peptidomics aim to identify peptides from MS and especially MS/MS. These peptides are the analytical endpoints in the case of peptidomics or are used for protein inference in the case of proteomics. Mass spectrometry based peptide identification is most straightforward if the genome of the organism under investigation is known. The decreasing time and costs of genome sequencing 
led to an increasing number of invertebrates having their transcriptome and/or genome sequenced and annotated which benefits future proteomic and peptidomic studies. Another cornerstone of efficient MS/MS data analysis is the expansion of MS/MS spectral databases. Proteomic MS/MS databases such as PRIDE [34] allow spectral matching of experimental MS/MS spectra with database-derived spectra (see further). There are nowadays neuropeptide information databases that also contain neuropeptide fragmentation spectra, such as SwePep [35]. More general neuropeptide databases are EROP-Moscow [36], PeptideDB [37] and Peptidome [38]. These all contain useful information, including numerous invertebrate sequences, aiding peptidomics and functional characterization experiments.

\section{$2.1 \quad$ Sample preparation}

The pioneering peptidomics experiments on invertebrates and vertebrates showed that there was a qualitative difference between samples from both groups reflected in the ratio of bioactive peptides to proteolytic peptides $[39,40]$. Vertebrate tissues are more prone to proteolytic degradation and require more stringent experimental conditions (low temperature, boiling, denaturing agents) in order to avoid contamination of the peptide extract by peptides originating from protein degradation. Invertebrate central nervous system (CNS) tissue, even separate cells, can be cleanly dissected and subsequent extraction procedures can enrich the sample with neuropeptides (see table 1 for the different peptidomics experiments on invertebrates) [40]. Whole-animal extracts (like for C. elegans [41]) usually require additional cleaning steps (like delipidation [42]). The highest quality of peptidomic extracts is achieved when neuroendocrine cell lines are available, whereby the cells themselves - or the secreted peptides after stimulation - can be extracted $[43,44]$. In many invertebrates, extraction can often be skipped and tissues may be analyzed through direct peptide profiling, in which whole tissues or organs are covered with a layer of matrix and directly analyzed through matrixassisted laser desorption/ionization time-of-flight (MALDI-TOF) MS [45-47]. A recent development in sample preparation is the peptidomic profiling of paraformaldehyde-fixed immunolabeled neurons of the American cockroach Periplaneta americana [48], which enables the targeted peptidomic analysis of predefined cells. 


\subsection{MS data analysis}

The most straightforward identification of neuropeptides from MS data consists of comparing experimental peptide masses (MS1) with theoretical masses from a database (Fig. 2). Neuropeptide precursors can be found in genomics data by homology searches or multiple alignment tools [49], but there also exist bioinformatic methods to predict new possible precursors based on signal sequence and cleavage site occurrence and the presence of internal repeats, a precursor hallmark that is typical for invertebrates [50]. Afterwards, the peptide precursors are cleaved in silico by a cleavage site prediction tool such as NeuroPred [51] and the mass of the fragments is calculated. This approach requires prior knowledge of possible post-translational modifications. Bioactive peptide databases [36-38] also usually give the mono-isotopic mass and already contain information on possible modifications. These databases are of course only for species whose genome was already sequenced and annotated. Mass matching should be backed up by (previous) MS/MS experiments to confirm the identities of the putative neuropeptides.

MS/MS data analysis of peptidomic experiments (Fig. 2) is inherently more difficult than for bottom-up proteomics where a protein is cleaved by trypsin. This is due to the general lack of C-terminal basic residues (which results in less predictable fragmentation patterns), more post-translational modifications and the fact that standard sequence database search engines require a proteolytic protein to be chosen to restrict the search space. Nonetheless, sequence database search robots like Mascot [52], Sequest [53] and X!Tandem [54] are a quick first step and will identify a decent amount of peptides if the genomic data is available for that species. Database searching algorithms are more accurate if re-scoring algorithms are used [55]. Peptidomics generally results in less peptide identifications than proteomics, and is therefore more amenable to manual or software-aided validation, which is strongly advised [56]. Searching against precursor databases (instead of the whole genome) increases the number of identifications (scoring functions usually give more significant scores if the database is smaller) and is justified if the selective extraction results in very low or negligible concentrations of proteolytic "background" peptides. Peptidomic database searches can also provide a basis for extra peptide identifications by clustering the high-quality unidentified spectra with the previously identified spectra. This allows to map modifications and isoforms on peptides identified by the database search [57]. 


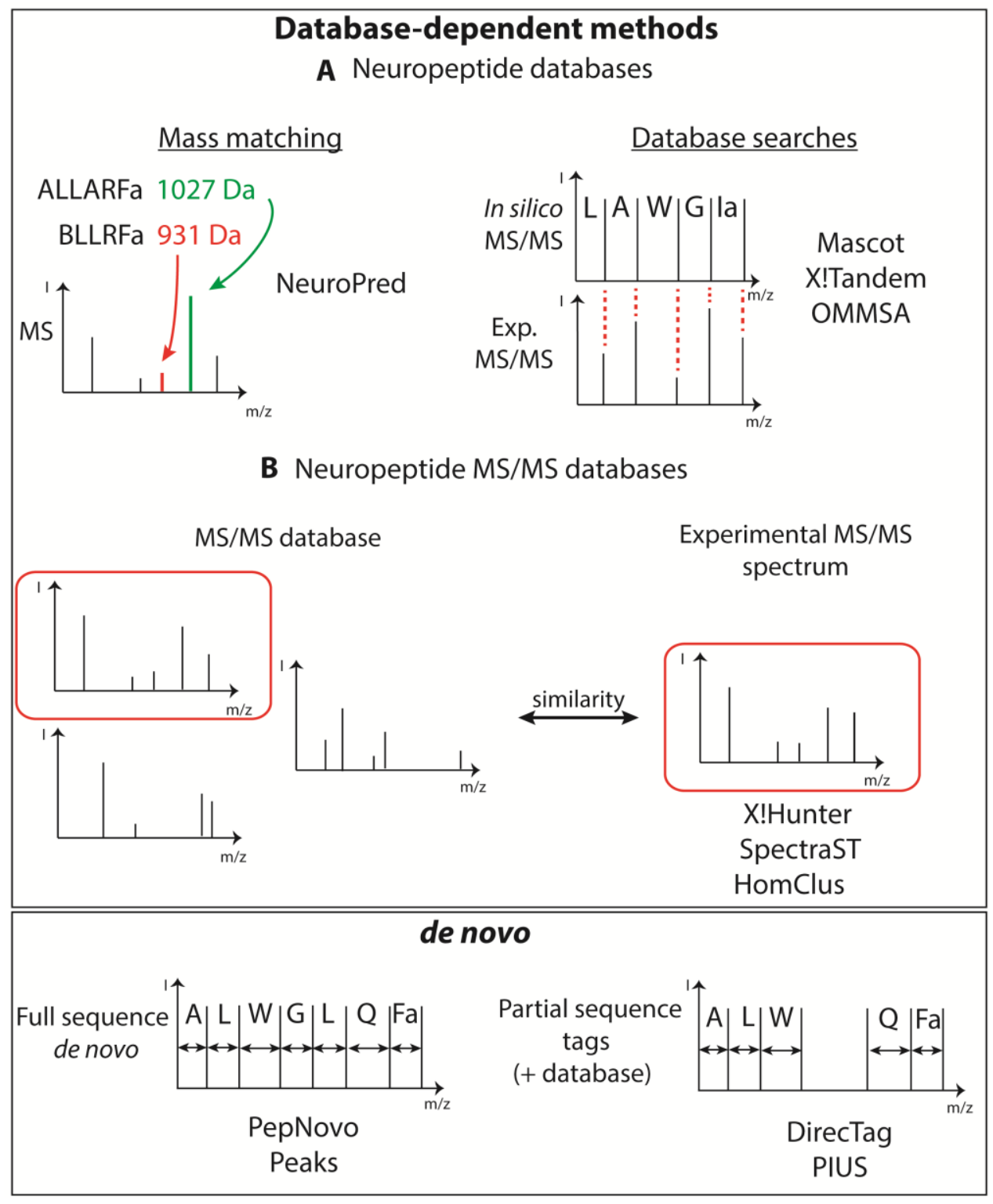

Fig. 2: Mass spectrometry based methods for endogenous peptide identification. Both databasedependent and de novo methods are schematically represented. Database-dependent methods include (A) mass matching based on single MS spectra, MS/MS-based database searches and (B) spectral matching. Mass matching requires databases with known neuropeptides or accurate prediction of genes and cleavage sites to calculate peptide masses from genomic databases. Database search engines score the similarities between theoretical and experimental MS/MS spectra. MS/MS databases allow searching for highly similar spectra. Clustering of MS/MS spectra can be used to find new modifications within an MS/MS dataset or to cluster MS/MS spectra of related species by similarity. De novo methods can be used independently or in combination with partial sequence tags to map peptides to the proteome or the genome. 
Table 1. Summary of recent invertebrate peptidomic experiments for the identification of novel neuropeptides. Organism and organ/tissue from which the neuropeptides were extracted are listed. Invertebrate neuropeptides identified by MS (not necessarily in genome wide screenings) prior to 2006 are listed in Hummon et al. [58]. CNS, central nervous system; CC, corpora cardiaca; CA, corpora allata; TG, thoracic ganglion.

\begin{tabular}{|c|c|c|}
\hline Organism/Classification & Organ & Reference \\
\hline \multicolumn{3}{|l|}{ Echinodermata } \\
\hline Strongylocentrotus purpuratus & radial nerve tissue & [59] \\
\hline \multicolumn{3}{|l|}{ Nematoda } \\
\hline Ascaris suum & heads & [60] \\
\hline Caenorhadbitis elegans & whole organism & {$[41]$} \\
\hline \multicolumn{3}{|l|}{$\begin{array}{l}\text { Chordata } \\
\text { Ascidiacea }\end{array}$} \\
\hline Ciona intestinalis & neural tissue & [61] \\
\hline \multicolumn{3}{|l|}{$\begin{array}{c}\text { Arthropoda } \\
\text { Insecta } \\
\text { Blattodea }\end{array}$} \\
\hline Blatta orientalis & CC, CA, neurons & {$[62]$} \\
\hline Deropeltis spec. & $\mathrm{CC}, \mathrm{CA}$, neurons & {$[62]$} \\
\hline Eurycotis floridana & CC, CA, neurons & [62] \\
\hline Neostylopyga rhombifolia & $\mathrm{CC}, \mathrm{CA}$, neurons & {$[62]$} \\
\hline Periplaneta americana & $\mathrm{CC}, \mathrm{CA}$, neurons & {$[62]$} \\
\hline Periplaneta australasiae & $\mathrm{CC}, \mathrm{CA}$, neurons & {$[62]$} \\
\hline Periplaneta brunnea & $\mathrm{CC}, \mathrm{CA}$, neurons & {$[62]$} \\
\hline Periplaneta fuliginosa & $\mathrm{CC}, \mathrm{CA}$, neurons & [62] \\
\hline Shelfordella lateralis & $\mathrm{CC}, \mathrm{CA}$, neurons & {$[62]$} \\
\hline \multicolumn{3}{|l|}{ Coleoptera } \\
\hline Tribolium castaneum & CNS tissue & {$[40,63]$} \\
\hline \multicolumn{3}{|l|}{ Diptera } \\
\hline Aedes aegypti & CNS tissue, $\mathrm{CC}$, midgut, antennal lobe & {$[64,65]$} \\
\hline Delia radicum & $\mathrm{CNS}$ & {$[66]$} \\
\hline Drosophila melanogaster & CNS, neurohemal organs & {$[40,67]$} \\
\hline Glossina morsitans & $\mathrm{CNS}, \mathrm{CC}, \mathrm{CA}$ & [68] \\
\hline Sarcophaga bullata & $\mathrm{CNS}$ & [69] \\
\hline \multicolumn{3}{|l|}{ Hemiptera } \\
\hline Acrosternum hilare & $\mathrm{CC}$, neurohemal organs & {$[46]$} \\
\hline Acyrthosiphon pisum & brain & {$[70]$} \\
\hline Banasa dimiata & $\mathrm{CC}$, neurohemal organs & {$[46]$} \\
\hline Euschistus servus & $\mathrm{CC}$, neurohemal organs & [46] \\
\hline Nezara viridula & $\mathrm{CC}$, neurohemal organs & {$[46]$} \\
\hline Rhodnius prolixus & CNS tissue & [71] \\
\hline \multicolumn{3}{|l|}{ Hymenoptera } \\
\hline Apis mellifera & $\mathrm{CNS}$ & {$[72,73]$} \\
\hline
\end{tabular}




\begin{tabular}{|c|c|c|}
\hline Nasonia vitripennis & CNS ganglia, $\mathrm{CA}$ & {$[74]$} \\
\hline \multicolumn{3}{|l|}{ Lepidoptera } \\
\hline Bombyx mori & brain, $\mathrm{CC}, \mathrm{CA}$ & [75] \\
\hline Galleria mellonella & neuroendocrine tissue & [71] \\
\hline \multicolumn{3}{|c|}{ Mantophasmatodea } \\
\hline Mantophasma kudubergense & $\mathrm{CC}$, neurohemal organs & {$[44]$} \\
\hline Namaquaphasma ookiepense & $\mathrm{CC}$, neurohemal organs & [44] \\
\hline Striatophasma nauklutftense & $\mathrm{CC}$, neurohemal organs & [44] \\
\hline \multicolumn{3}{|l|}{ Orthoptera } \\
\hline Locusta migratoria & CC, pars intercerebralis & {$[24,56,73,74]$} \\
\hline Schistocerca gregaria & $\mathrm{CA}$ & {$[73,74]$} \\
\hline \multicolumn{3}{|l|}{$\begin{array}{r}\text { Malacostraca } \\
\text { Decapoda }\end{array}$} \\
\hline Callinectes sapidus & Pericardial organs, sinus gland & {$[79-83]$} \\
\hline Cancer borealis & brain, thoracic ganglion & {$[83,84]$} \\
\hline Cancer productus & TG & [85] \\
\hline Carcinus maenas & Pericardial organs & {$[80]$} \\
\hline Hyas lyratus & TG & [85] \\
\hline Hemigrapsus nudus & TG & [85] \\
\hline Oregonia gracilis & TG & {$[85]$} \\
\hline Panulirus interruptus & Sinus gland & [83] \\
\hline Telmessus cheiragonus & TG & [85] \\
\hline \multicolumn{3}{|l|}{ Branchiopoda } \\
\hline Daphnia pulex & brain-optic ganglia & {$[86]$} \\
\hline \multicolumn{3}{|l|}{$\begin{array}{l}\text { Mollusca } \\
\text { Gastropoda }\end{array}$} \\
\hline Aplysia californica & neurons & {$[87]$} \\
\hline Lymnaea stagnalis & Neurons, penial complex & {$[88,89]$} \\
\hline
\end{tabular}

On the other end of the MS/MS analysis spectrum are de novo sequencing tools (Fig. 2), like PepNovo [90] and Peaks [91], which do not use prior information to identify peptides. This has the advantage of not relying on genomic information, correct protein translation and presumed modifications or cleavage sites. However, only high-quality spectra can be fully sequenced de novo. Sequencing multiple short stretches (PSTs or partial sequence tags) of an MS/MS spectrum is usually feasible by programs like DirecTag [92]. If multiple ( $\mathrm{n}$ 1) PSTs are available for a single MS/MS spectrum (or a completely sequenced spectrum), methods exist that will map these PSTs to all six reading frames of a genome [59,93,94]. This is interesting since it circumvents problems related to annotation (if the organism has no close evolutionary relatives with explored neuropeptidomes) and has for example been successfully 
applied to the sea urchin [59]. De novo sequencing tags are also used to limit the size of a database in a database search [95].

MS/MS data from peptidomics experiments should ideally be publically available for spectral matching by algorithms such as SpectraST [96], X!Hunter [97] and BiblioSpec [98]. The lack of a centralized public database reflects the less matured stage of peptidomics compared to proteomics. However, there are various groups that have their own stored neuropeptide MS/MS data. Clustering of peptidomic MS/MS data from species (of which one is well characterized) allows the identification of neuropeptides, even if the genome is not or incompletely sequenced [78]. Taken together, the ongoing sequencing efforts, the expanding neuropeptide spectral databases and the peptidomics specific bioinformatics approaches [99] have developed the field of peptidomics to a point where an organism's neuropeptidome can be charted in depth within reasonable time.

\section{Differential peptidomics}

Differential peptidomics focuses on the comparison of peptide profiles between biological samples and correlates peptide expression levels to a phenotype of interest, ultimately formulating working hypotheses on the involvement of the neuropeptide (Fig. 3A). The peptidome-wide screening of neuropeptides is a good starting point for further functional characterization and differential peptidomics is as such complementary to the reverse approaches discussed later on. Differential peptidomics can be separated into two subdomains: focusing on qualitative or quantitative comparisons. Historically, differential peptidomics mainly focused on qualitative comparisons between samples, identifying peptide peaks that are (near)-absent in one sample but abundant in another. More recently, quantitative peptidomics studies are gaining traction and are being used for the - usually relative - quantification of peptide profiles. Various approaches exist for both qualitative and quantitative differential peptidomics and all have potential uses within the field of invertebrate peptidomics.

\subsection{Qualitative comparisons}

Qualitative differential peptidomics essentially does not differ much from standard peptidomics techniques used to detect and identify peptide profiles. In qualitative differential 
peptidomics, peptide profiles are attained using standardized procedures, usually through offline reverse phase high-performance liquid chromatography (RP-HPLC) and subsequent MALDI-TOF MS [100,101]. For single invertebrate tissues, the extraction and HPLC step is often even skipped and extracts are analyzed and compared through direct profiling (see section 2.1) $[45,46]$. By using the same standardized procedures to extract and detect peptides from samples, it is possible to manually compare peptide profiles to detect peaks absent in one sample but abundant in another.

Qualitative comparisons have shown their use in several invertebrate research domains where large differences in peptide profiles are expected. For example, qualitative differential peptidomics techniques were used to identify immune-inducible peptides in the hemolymph of D. melanogaster [102-104]. Again in D. melanogaster, qualitative comparisons were used to show that that the peptidome of its neurohemal organs does not radically change during metamorphosis [105]. Peptide profiles were similarly compared to identify peptides potentially contributing to phase transition in locusts $[106,107]$ and to diapausing Colorado potato beetles (Leptinotarsa decemlineata) [100]. In C. elegans, qualitative comparisons were used to profile a set of peptide processing enzymes, including proprotein convertases required for cleaving peptides from their proprotein precursors $[5,108]$.

Qualitative comparisons are also commonly used to profile evolutionary conservation of neuropeptides between closely related species and were used, for example, for comparisons between C. elegans and Caenorhabditis briggsae [101] and different insect species $[45,46,109]$.

\subsection{Quantitative peptidomics}

Quantitative peptidomics is largely based on quantitative proteomics, with one main exception: popular gel-based proteomics methods cannot be used for quantitative peptidomics as peptides do not separate well on gels due to their small size. Many of the remaining differential gel-free proteomics methods have been successfully adapted for use in quantitative peptidomics, including both label-based and label-free methods. However, while many qualitative proteomics approaches have been largely automated [110,111], quantitative peptidomics often requires laborious manual analysis of data [72,80,112]. 


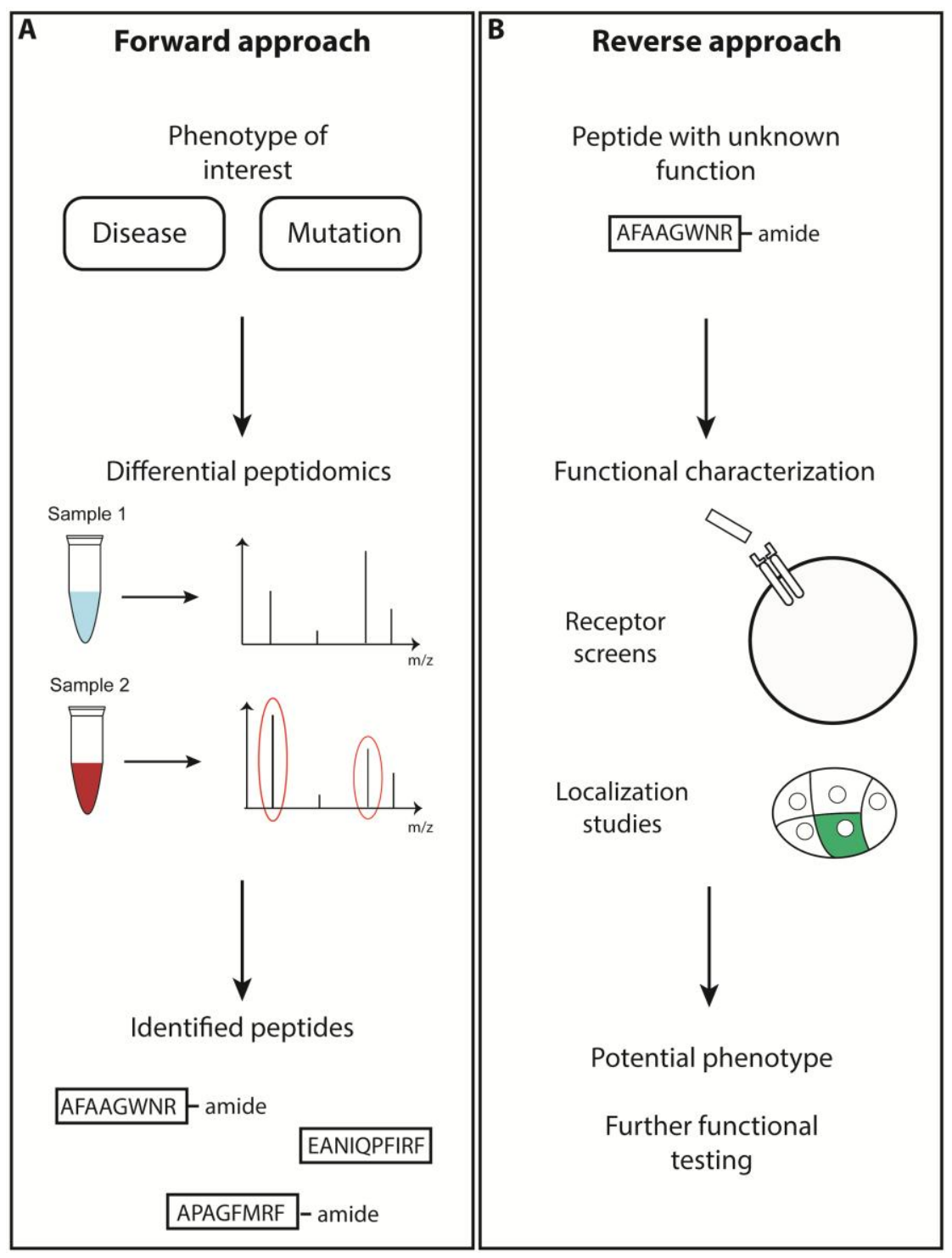

Fig. 3: Schematic overview of potential approaches for functional peptidomics. A In a forward approach, a phenotype of interest (e.g. a disease or a clear phenotype resulting from a singular mutation) is chosen for study, with the intention of discovering which peptides influence it. Differential peptidomics techniques, comparing control and experimental samples, are used in order to construct a list of peptides that potentially contribute to the phenotype of interest. B Using the reverse approach, an identified peptide (or receptor) with unknown function is used as the object of study. By functionally characterizing the peptide (e.g. through receptor screens or localization studies), the phenotypes it influences may eventually be revealed.

Label-based techniques have the benefit that differentially labeled samples can be pooled prior to LC-MS analysis, reducing between-run variability. Label-based differential peptidomics depend on either metabolic or chemical differential labeling in order to discern samples during mass spectrometry. The metabolic labeling technique that is most compatible 
with multicellular organisms is the stable isotope labeling with amino acids in cell cultures (SILAC) [113] technique. In SILAC, cell cultures (or animals) are provided with stable isotopic variants of amino acids, after which they are integrated during growth. While complete incorporation of these isotopic variants is difficult in larger species [114], SILAC has already been adapted for use in both D. melanogaster [115] and C. elegans [114] proteomics, implying that SILAC may be used for peptidomics in these species as well. Chemical labeling differs from metabolic labeling in that samples are labeled after extraction, instead of during growth, potentially adding more experimental variation to the peptidomics experiment. Popular isotopic chemical labels used for peptidomics include 4trimethylammoniumbutyryl (TMAB) [112] and succinic anhydride [112,116]. These labels are often chosen due to their ability to bind amines, in contrast to cysteine-binding labels, such as isotope-coded affinity tags [117], as not all endogenous peptides contain cysteine residues. Amine-binding isobaric tags such as tandem mass tags (TMT) [118], isobaric tags for relative and absolute quantification (iTRAQ) [119], and N,N-dimethyl leucines (DiLeu) [79], which are generally used for differential proteomics, have also been adapted for use in differential peptidomics. Isobaric tags differ from isotopic tags in that the total mass of each label does not differ from each other, but each different label releases a reporter ion with different mass upon fragmentation during mass spectrometric analysis, thus still allowing differentiation of each sample [118]. In addition to these label-based techniques, label-free proteomics techniques have also been successfully adapted for use in peptidomics [120]. Label-free techniques require separate LC-MS runs for each sample, thus making between run-variability a potential confounding factor in quantitative analysis [121]. However, labelfree techniques also have advantages over chemical labeling techniques, including the ability to quantify peptides with modified amine residues. For a more comprehensive review regarding techniques used for quantitative peptidomics, including advantages and disadvantages of each technique, see Romanova et al. [122].

Invertebrate organisms are ideally suited for high-throughput quantitative peptidomics due to the relatively low complexity of their peptidome and the ease by which single tissues can be collected, extracted and compared, further lowering sample complexity. Nevertheless, only few quantitative peptidomics studies have been performed in invertebrates. In the large sea slug Aplysia californica, a model often used for the study of neurobiology, learning and behavior, both succinic anhydride and isobaric iTRAQ tags were successfully employed to compare neuropeptide profiles between individual neurons and tissue, revealing the relative 
ease by which peptides can be quantified in invertebrate models [116]. In the honey bee $A$. mellifera, isotopic labeling with succinic anhydride was used to compare brain neuropeptide profiles between nurses and foragers and between nectar and pollen foragers, through which 8 highly dynamic peptides that may be involved in the regulation of honey bee behavior were identified [72]. Isobaric DiLeu labeling was employed to determine changes in endogenous peptide concentrations in the gut and salivary glands of the assassin bug Rhodnius prolixus in relation to feeding, revealing potential peptides involved in the postprandial endocrine response in this disease vector [71]. In the same vein, isobaric and isotopic labeling were used to investigate the neuropeptidergic responses of crustacean species to salinity stress [80] and feeding [123] respectively.

Invertebrate quantitative peptidomics has a promising future ahead. The studies listed above illustrate how tissues [71,72] or even single neurons [116] can be compared, which can be invaluable for the study of (neuro-)endocrinological modulation of processes such as behavior in invertebrate model systems. It is important to note that such forward studies (Fig. 3) only provide a list of interesting targets, and that their involvement in the studied phenotype needs to be validated. Several invertebrate models generally allow straightforward validation of data due to the existence of extensive genetic toolsets (see section 4.3).

Importantly, many biological processes in invertebrates are regulated by the endocrine system, although thorough understanding of this endocrine regulation is often lacking. The nematode $C$. elegans is often used as a model organism for the study of aging, and endocrine signaling has a key role in the regulation of longevity in this worm (as reviewed by Kleemann and Murphy [124] and Panowski and Dillin [125]). However, the identities of the signaling molecules involved in this endocrine regulation of aging are largely unknown. As C. elegans has a rich diversity in both endogenous neuropeptides and peptide GPCRs (as reviewed by Frooninckx et al. [8]), it seems likely that neuropeptidergic signaling is at least partly responsible for this endocrine regulation of longevity. Quantitative peptidomics may provide the tools necessary to finally solve these remaining mysteries.

\section{Functional characterization of neuropeptides}

The majority of neuropeptides exert their function by binding to plasma membrane-associated receptors known as G-protein coupled receptors (GPCRs), resulting in the activation of 
intracellular signaling pathways (for encompassing reviews about neuropeptide GPCRs, see the reviews by Frooninckx et al. [8] about $C$. elegans GPCRs and by Caers et al. [9] about insect GPCRs). While the previously discussed differential peptidomics techniques can be used to investigate the involvement of neuropeptides (Fig. 3A) in the regulation of a phenotype of interest, neuropeptides are often studied in reverse (Fig. 3B). By studying and functionally characterizing an identified peptide (or receptor), the phenotypes it influences may eventually be revealed. Here we will discuss different strategies for identifying neuropeptide-receptor pairs, peptide and receptor localization and functional tests. Studies in the popular model organisms $D$. melanogaster and $C$. elegans that are based on peptidomewide screening and characterization are presented in table 2.

\subsection{Deorphanization and receptor identification}

In the past, novel GPCRs were often identified by screening cDNA libraries with lowstringency oligonucleotide probes [126] and degenerate polymerase chain reaction (PCR) experimental techniques [127]. One of the drawbacks of this approach, in which GPCRs are identified exclusively via homology, is that the endogenous ligands are almost always unknown, resulting in so called 'orphan receptors' [128].

An essential step in the characterization of a predicted neuropeptide GPCR is the identification of its natural ligand(s), called 'deorphanization'. Knowledge of functionally active neuropeptide-receptor couples and GPCR affinity is crucial to understand how neuropeptides function and modulate neural circuits. When a new neuropeptide is found (e.g. by detection in a sample or a de novo prediction), one of the main questions that arises is which receptor(s) it activates to exert its function. The same goes for novel neuropeptide receptors: what is the range of ligands that bind this receptor and at what affinity? In the postgenomic era these questions are commonly answered using a 'reverse pharmacology' approach (Fig. 4), in which GPCRs are heterologous expressed in cultured cells and used as targets for screening the neuropeptidome.

\subsubsection{Mammalian cells as heterologous expression systems for GPCR screens}

Throughout the years, immortalized mammalian cell lines have become very popular expression systems for the deorphanization of GPCRs. The most widely used host mammalian 
Table 2. C. elegans and D. melanogaster neuropeptide receptors characterized by a peptidome-wide approach. Table partially adapted from [8,9,129].

\begin{tabular}{|c|c|c|c|c|}
\hline Organism & Receptor name & $\begin{array}{l}\text { Receptor accession } \\
\text { number }\end{array}$ & Activating peptides & References \\
\hline \multirow{15}{*}{ C. elegans } & CKR-2F & Y39A3B.5c/d & NLP12a; NLP-12b & [130] \\
\hline & EGL-6A & C46F4.1a & FPL-10; FLP-17a, FLP-17b & [131] \\
\hline & FRPR-18A & T19F4.1a & FLP-2a; FLP-2b & [132] \\
\hline & FRPR-18B & T19F4.1b & FLP-2a; FLP-2b & [132] \\
\hline & FRPR-3 & C26F1.6 & FLP-7a; FLP-11a & [133] \\
\hline & NPR-1 & C39E6.6 & FLP-18b; FLP-18c; FLP-18d; FLP-18e; FLP-18f; FLP-18g ; FLP-21 & [135] \\
\hline & NPR-10A & C53C7.1a & $\begin{array}{l}\text { FLP-3a; FLP-3c; FLP-3e; FLP-3f; FLP-3g; FLP-3h; FLP-18c; FLP- } \\
\text { 18d; FLP-18e; FLP-18f; FLP-18g }\end{array}$ & [136] \\
\hline & NPR-10B & C53C7.1b & $\begin{array}{l}\text { FLP-3a; FLP-3c; FLP-3e; FLP-3f; FLP-3g; FLP-3h; FLP-18c; FLP- } \\
\text { 18d; FLP-18e; FLP-18f; FLP-18g }\end{array}$ & [136] \\
\hline & NPR-11 & C25G6.5 & NLP-1a; FPL-1f; FLP-5b; FLP-14; FLP-18c; FLP-21 & [136] \\
\hline & NPR-5B & Y58G8A.4b & $\begin{array}{l}\text { FLP-1b; FLP-3a; FLP-3f; FLP-3g; FLP-3h; FLP-18b; FLP-18c; } \\
\text { FLP18-d; FLP-18e; FLP-18f; FLP-18g; FLP-21 }\end{array}$ & {$[136,139,140]$} \\
\hline & NPR-6 & F41E7.3 & FLP-15a & [136] \\
\hline & NTR-1 & T07D10.2 & NTC-1 & [13] \\
\hline & PDFR-1A & C13B9.4a & PDF-1a; PDF-1b; PDF-2 & [141] \\
\hline & PDFR-1B & C13B9.4b & PDF-1a; PDF-1b; PDF-2 & [141] \\
\hline & PDFR-1C & C13B9.4c & PDF-1a; PDF-1b; PDF-2 & [141] \\
\hline \multirow[t]{2}{*}{ D. melanogaster } & AKHR & CG11325 & $\mathrm{AKH}$ & [142] \\
\hline & ASTA-R1 & CG2872 & ASTA1-4 & {$[143,144]$} \\
\hline
\end{tabular}




\begin{tabular}{|c|c|c|c|}
\hline ASTA-R2 & CG10001 & ASTA1-4 & {$[144,145]$} \\
\hline ASTC-R1 & CG7285 & ASTC & [146] \\
\hline ASTC-R2 & CG13702 & ASTC & [146] \\
\hline CAPAR & CG14575 & CAPA-PVK1-2 & [147] \\
\hline CCHa1-R & CG30106 & CCHa1-2 & [148] \\
\hline CCHa2-R & CG14593 & CCHa1-2 & [148] \\
\hline CRZR & CG10698 & CRZ & [149] \\
\hline FMRFaR & CG2114 & dFMRFa1-8 & {$[150]$} \\
\hline MSR1 & CG8985 & DMS & {$[151]$} \\
\hline MSR2 & CG13803 & DMS & [151] \\
\hline PK1-R & CG9918 & CAPA-PK1 & [152] \\
\hline PK2-R1 & CG8784 & Hugin-PK2 & [153] \\
\hline PK2-R2 & CG8795 & CAPA-PK2 & [153] \\
\hline Proc-R & CG6986 & Proctolin & [154] \\
\hline SPR & CG16752 & SP; MIP1-5 & {$[155,156]$} \\
\hline DH31-R & CG32843 & $\mathrm{DH}_{31}$ & [157] \\
\hline CCKLR-17D1 & CG42301 & DSK1-2 & [158] \\
\hline DH44-R1 & CG8422 & $\mathrm{DH}_{44}$ & [159] \\
\hline DH44-R2 & CG12370 & $\mathrm{DH}_{44}$ & [160] \\
\hline CCAP-R & CG33344 & CCAP & [161] \\
\hline ETHR & CG5911 & ETH1-2 & [162] \\
\hline LGR1 & CG7665 & GPA2/GPB5 & [163] \\
\hline LKR & CG10626 & Leucokinin & [164] \\
\hline NPFR & CG1147 & NPF & [165] \\
\hline PDFR & CG13758 & PDF & {$[166,167]$} \\
\hline RK & CG8930 & Burs & [168] \\
\hline RYa-R & CG5811 & $\mathrm{RYa}$ & [169] \\
\hline SNPF-R & CG7395 & sNPF1-4 & {$[170]$} \\
\hline SIFaR & CG10823 & SIFa & [171] \\
\hline CCKLR-17D3 & CG32540 & DSK1-2 & [172] \\
\hline TKR86C & CG6515 & DTK-1-6 & [173] \\
\hline TKR99D & CG7887 & DTK-6 & [174] \\
\hline TrissinR & CG34381 & Trissin & [175] \\
\hline
\end{tabular}


cell lines are Chinese Hamster Ovary (CHO) cells and Human Embryonic Kidney (HEK) 293 cells due to their high efficiency of transfection and faithful translation and processing of proteins [176,177]. Alternative expression systems include yeast and insect cells as well as Xenopus laevis oocytes and melanophores [164,178-182].

In addition to selecting an appropriate heterologous expression system, an accurate and broadly applicable platform to measure GPCR activation is required. By monitoring downstream events of the GPCR signaling transduction cascade, such as second messenger activity and transcription of target genes, many different strategies have been developed for the detection of GPCR activation in mammalian cells [183,184]. Many of the cell-based assays rely on the expression of promiscuous G-protein $\alpha$ subunits or chimeric G-proteins, which renders them applicable to all GPCRs regardless of the endogenous G-protein coupling and consequently eliminates the need for prior knowledge of the interacting G-protein $[185,186]$.

\subsubsection{Intracellular calcium mobilization}

Calcium mobilization assays lend themselves perfectly to high-throughput orphan receptor screening and are therefore routinely used in both pharmaceutical companies and academic institutes. They detect GPCR activation through changes in intracellular calcium $\left(\mathrm{Ca}^{2+}\right)$ concentration, which acts as a secondary messenger. The resulting increase in intracellular $\mathrm{Ca}^{2+}$ concentration can be monitored using fluorescent dyes, such as Fluo-3 and Fluo-4, or $\mathrm{Ca}^{2+}$-sensitive biosensors, such as aequorin, a bioluminescent protein isolated from the hydrozoan jellyfish Aequorea victoria [187].

\subsubsection{Intracellular cAMP concentration}

Measuring the change in intracellular cyclic adenosine 3',5'-monophosphate (cAMP) levels is another (deorphanization) strategy, which, similar to the principle of calcium mobilization assays, relies on a second messenger molecule as a functional readout of $\mathrm{G} \alpha_{\mathrm{s}}$-coupled GPCR activation. A variety of cAMP detection methods have been developed to quantify the activation of such GPCRs. They can essentially be divided into two broad categories: (1) accumulation assays, which are based on the competition between cellular cAMP and 
exogenously added labeled cAMP for binding to a limited number of anti-cAMP antibody binding sites, and (2) reporter gene assays, in which receptor activation is measured via changes in the expression level of a selected reporter gene (as reviewed by Gabriel et al. [188] and Williams [189]).

\subsubsection{3 $\beta$-arrestin tagging}

Another popular deorphanization method, $\beta$-arrestin tagging, relies on a universally shared GPCR feature instead of specific $G$ protein signaling pathways that differ from receptor to receptor. In particular, it depends on the way by which signaling is terminated. Almost all GPCRs are deactivated by GPCR-regulatory-kinases (GRKs) which phosphorylate the Cterminal side of the receptor. This results in recruitment of $\beta$-arrestins from the cytosol to the phosphorylated sites and subsequent receptor desensitization and internalization [128]. By tagging $\beta$-arrestin molecules with a fluorescent protein such as GFP, it is possible to visualize their translocation from the cytosol to the cell membrane (and vice versa). Thus, by means of a protein redistribution assay it is possible to visualize GPCR (de)activation in living cells [190]. Using this technique, several GPCRs in Drosophila have been deorphaned after transiently expressing them in HEK cells [191].

As $\beta$-arrestin tagging historically required automated confocal systems and subsequent image analysis [184], this technique for GPCR deorphanization is less commonly used compared to more straightforward techniques measuring calcium mobilization or cAMP concentration. However, $\beta$-arrestin tagging provides some advantages, including that activity is measured upstream at the GPCR level - compared to downstream cAMP or calcium levels - and is thus completely independent of $\mathrm{G}$ protein activity [192]. Novel techniques utilizing $\beta$-arrestin tags no longer require laborious image analysis and are instead based on the detection of fluorescent or chemiluminescent reporter signals [193,194].

\subsubsection{A perspective on GPCR deorphanization in invertebrates}

A significant amount of initial work in the field of GPCR deorphanization was performed on D. melanogaster. In 1991, $\mathrm{Li}$ and colleagues were the first to clone and functionally characterized an insect GPCR [195], namely the Drosophila tachykinin-like receptor. After 


\section{Receptor deorphanization}

\section{Organism of interest}
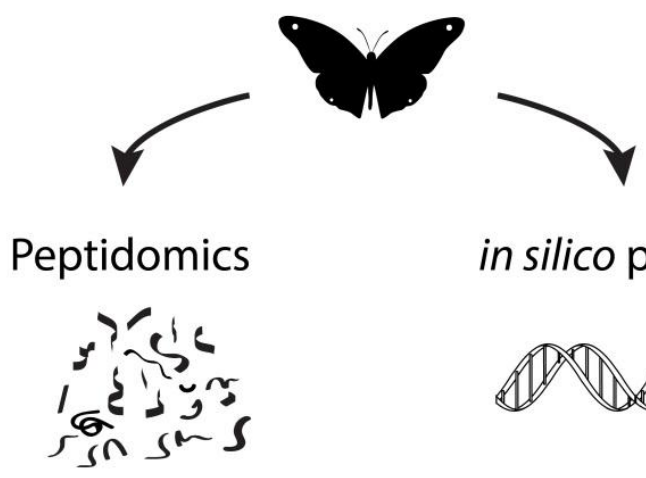

in silico prediction
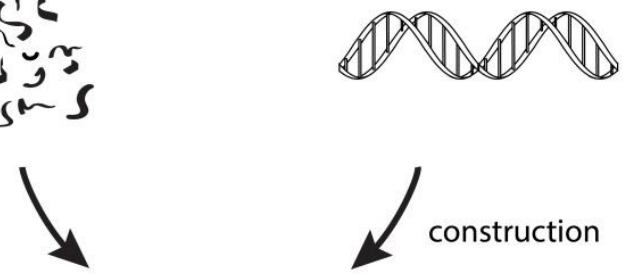

Peptide library
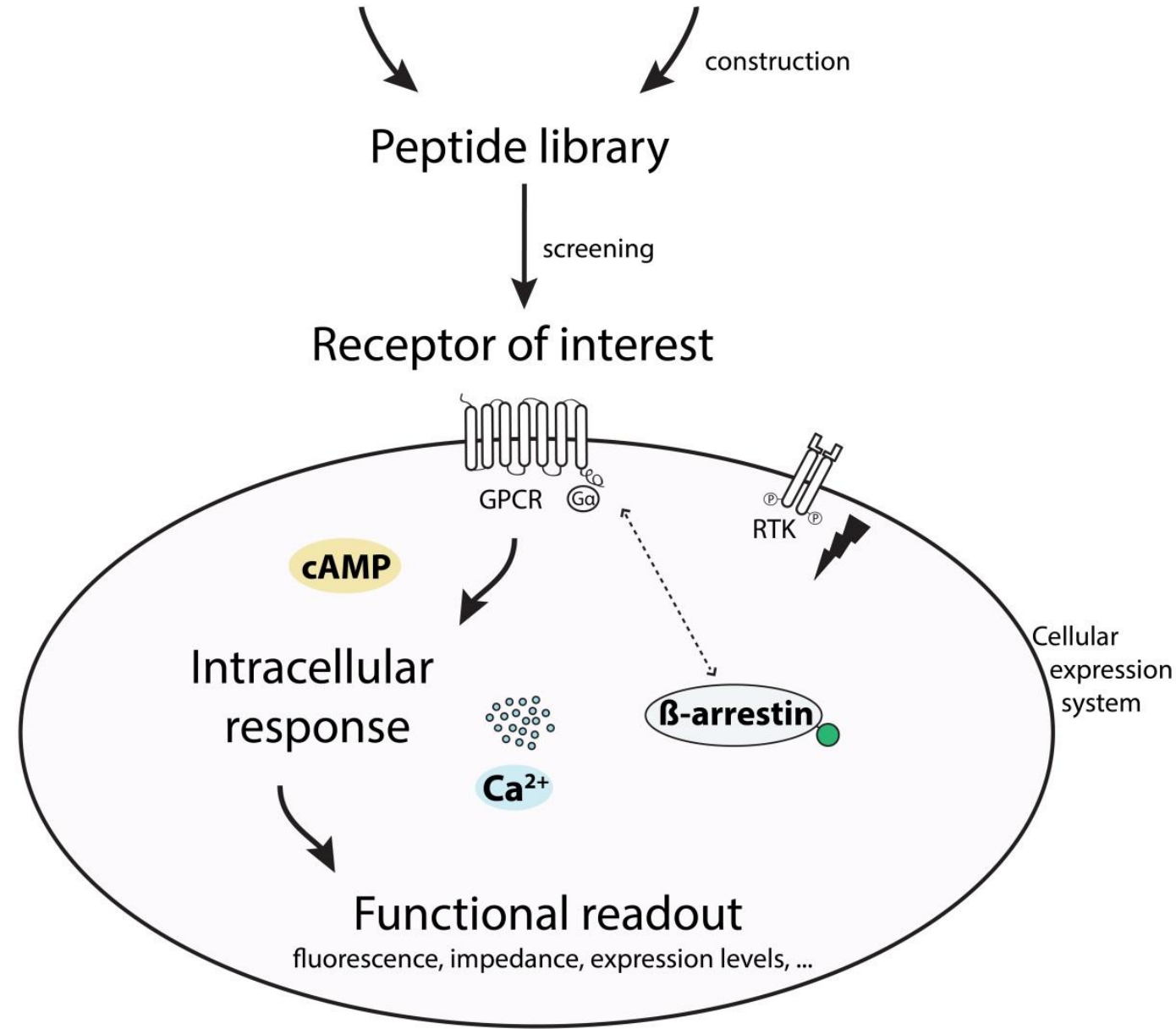

Fig. 4: Graphical overview of the different approaches leading to receptor deorphanization. Typically, a neuropeptide library (based on peptidomics data and/or in silico predictions) is used to screen for receptor-binding. The receptor of interest is expressed in cultured cells and one or more assays, often based on measuring increased concentrations of secondary messengers (such as cAMP or $\mathrm{Ca}^{2+}$ ), augmented fluorescence or altered impedance, are used to obtain a functional read-out of receptor activation for each potential ligand. Using this process, it is possible to identify the natural ligand(s) of putative neuropeptide receptors. 
publication of the D. melanogaster genome [196], the development of (neuro)-peptidomics accelerated. Based on genomic data, it became possible to predict a large number of neuropeptide receptors and neuropeptide precursors [197,198]. During the following years, over a dozen GPCR neuropeptide receptors were identified and their signaling systems characterized. A comprehensive overview of early D. melanogaster (neuro)peptide research can be found in the literature $[9,129,199]$.

While great progress was made in characterizing neuropeptides, even in the extensively studied model organisms D. melanogaster and C. elegans, the majority of neuropeptide receptors remain orphan, awaiting for their endogenous ligand(s) to be determined [8,9]. So far only $18 \%$ of the predicted C. elegans GPCRs (isoforms included) could be deorphaned [200]. A recent large-scale initiative, titled "the Peptide-GPCR project", aims to bridge this gap by matching all predicted peptide $C$. elegans GPCRs tot their cognate neuropeptide ligand(s). The project's goal is to characterize novel neuropeptide-GPCR couples and GPCR affinity using a combined reverse pharmacology approach. Peptide GPCRs will be randomly screened with a library of over 260 peptides belonging to the FMRFamide-related peptide and neuropeptide-like protein families (Isabel Beets, Personal Communication). An in vitro calcium mobilization strategy allows screening of these peptides on all putative peptide GPCRs in a high-throughput manner. Community members are invited to steer the project's progression (via https://worm.peptide-gpcr.org/).

\subsubsection{Neuropeptides as receptor tyrosine kinase activators}

While GCPRs are by far the most common receptors for neuropeptides, some neuropeptides activate receptor tyrosine kinases (RTKs) instead. While high-throughput receptor screens are not as commonly used for receptor tyrosine kinases due to the lack of a unified cellular response to their activation, a cellular assay to study their activation using a microelectronic sensor array has been developed [201]. Additionally, receptor tyrosine kinases autophosphorylate when activated, which allows their activation to be studied using targeted antibodies in a western blot [202]. 


\subsection{Localization of neuropeptides}

Determining the expression patterns of neuropeptide genes can provide us with a great amount of information and clues as to their biological function. Likewise, knowledge about the cellular localization of the accompanying neuropeptide receptor can be important to deduce the possible role of the neuropeptide signaling system. There are several possible tools to study the distribution pattern of neuropeptides and their cognate receptors. The most popular are immunocytochemistry, in situ hybridization and the use of reporter genes. More recently, imaging mass spectrometry (IMS) [203] has emerged as a promising technique for identifying peptides and proteins and their spatial localization in tissues simultaneously based on their molecular masses.

\subsubsection{Immunocytochemistry}

Our knowledge about the distribution of neuropeptides and their receptors in the nervous system of invertebrates has been greatly advanced by the use of immunocytochemistry [204209]. This technique relies on specific antibodies to assess the presence of a protein or antigen in tissues and cells. The major drawback to using this approach for the localization of neuropeptides is cross-reactivity [210]. Many peptide antibodies do also recognize related or unrelated molecules due to sequence similarity with the proteins used to raise the antisera. As neuropeptides often exist in different isoforms and sequence similarities among members of the same neuropeptide family are readily apparent, it can be challenging to specifically detect the localization of a particular peptide by immunocytochemistry.

\subsubsection{In situ hybridization}

Knowing the DNA sequence of neuropeptides and their cognate receptors provides the opportunity to localize and detect the physical position of their corresponding messenger RNA sequences (mRNAs) by in situ hybridization. The core principle of this approach rests on hybridization between a labeled single-stranded nucleic acid probe and a complementary sequence within the target mRNA. The resulting duplexes can be visualized by standard label detection techniques. Traditional histochemical RNA detection methods use radiolabeled complementary DNA or RNA strands for identifying specific mRNA species in tissue sections. Nowadays, non-radioactive hybridization probes have become a superior alternative 
over radioactive approaches [211]. As with immunocytochemistry, direct as well as indirect labeling methods are available. Wisely designed oligonucleotide probes allow for discrimination between closely related gene family members and different splice variants.

\subsubsection{Reporter genes}

Gene expression patterns can be visualized either directly by using nucleic acid probes (in situ hybridization) and antibodies (immunocytochemistry), or indirectly by using easily detectable reporter genes. To examine the spatial expression of neuropeptide genes, the promoter region of the neuropeptide precursor and the coding region of the reporter gene are fused together and the resulting transcriptional reporter constructs are then inserted into the organism. In addition, translational reporters can be used which include additional regulatory information that may be present in introns or 3'UTRs. These constructs comprise the entire genomic locus of the neuropeptide precursor gene (including 5'UTR, introns, exons and 3'UTRs) fused to the reporter gene coding sequence.

Genes encoding fluorescent proteins are frequently used as reporters of gene expression [212]. Naturally occurring fluorescent proteins, such as the green fluorescent protein (GFP) isolated from the jellyfish Aequorea victoria, and the red fluorescent protein (dsRed) derived from the sea anemone Discosoma sp., have, however, several undesirable physical properties such as reduced protein stability, decreased brightness and insufficient photostability, which limits their usefulness as an imaging tool [213]. Many of the adverse properties have been overcome by site-directed and random mutagenesis and this protein engineering created a plethora of reliable fluorescent protein variants in various spectral regions (blue, cyan, green, yellow, orange, red and far-red) [214].

C. elegans is especially well suited for the use of fluorescent protein markers for gene expression studies and protein localization [215]. The worm's small size and transparency facilitates non-invasive microscopy and allows for in vivo localization of neuropeptide signaling components. In addition, transgenic animals can be readily generated via microinjection of foreign DNA fragments into the distal arm of the gonad [216]. There are several approaches for generating reporter constructs in C. elegans [215], including standard cloning techniques [217,218] or a PCR-fusion based approach [219].

In Drosophila, the localization of neuropeptides can also be easily studied with reporter genes using the GAL4/UAS binary system [220,221]. GAL4, originally identified in the yeast 
Saccharomyces cerevisiae, activates the transcription of genes containing Upstream Activating Sequences (UAS) by directly binding to these regulatory elements. For the study of neuropeptide expression patterns, the GAL4 gene is placed under the control of a neuropeptide precursor promoter, while expression of the reporter gene is driven by the presence of the UAS element. As a result, the reporter gene will only be transcribed in the cells where GAL4 is present, this is to say, in cells where the neuropeptide precursor gene is usually active.

\subsubsection{MS imaging}

MALDI IMS combines spatial analysis with mass spectrometry to analyze the distribution of small molecules, such as peptides, in a tissue. In short, thin tissue sections - or in the case of smaller invertebrates, whole tissues - are mounted on a MALDI target and embedded in matrix, after which specific sites on the tissue can be excited using the MALDI laser [203,222]. MALDI IMS allows one to directly examine the spatial presence of known and predicted peptides in different tissues. Direct MS profiling of neuronal tissues, instead of using other histological techniques, bypasses the need for lengthy extraction procedures and allows for the creation of a detailed neuropeptide expression map.

IMS can be used for comparative or explorative analyses of different invertebrate tissues. The $\mathrm{Li}$ group pioneered the IMS characterization of crustaceans using various MS platforms on different species (as reviewed by $\mathrm{Yu}$ et al. [223]). For example, an IMS study on both pericardial organ and brain of the Jonah crab, Cancer borealis, elucidated the spatial relationship between multiple neuropeptide isoforms of the same family as well as the relative distributions of neuropeptide families [224]. In addition to planar 2D images, a detailed 3D map of the neuropeptide and lipid distribution in the C. borealis brain was created using 2D information of serial sections [225]. In the blue crab Callinectes sapidus, a combination of MALDI-TOF/TOF and MALDI-FT-ICR was performed to map the whole stomatogastric nervous system at the network level [226]. Other research groups have similarly adapted IMS for the mapping of peptide expression in other species. For example, MALDI IMS was successfully used to study neuropeptide localization in both the locust $S$. gregaria [227] and the cockroach Periplaneta americana [228]. In the honey bee A. mellifera, MALDI IMS was used to uncover the spatial and temporal distribution of specific neuropeptides in the worker brain, revealing a possible correlation between the localization of certain neuropeptides and age-related division of labor [229]. IMS analysis also revealed the localization of several 
peptides in the nervous structure of the parasitic nematode Ascaris suum, further showing that peptide expression profiles are largely unique for each nervous structure in this parasitic worm [230]. In the shrimp Penaeus monodon, IMS analysis revealed differential distribution of several neuropeptides over various neuronal tissues, and also resulted in the addition identification of a novel tachykinin-related peptide [231].

\subsection{Functional characterization}

Receptor identification and localization of the neuropeptide and its receptor provide valuable information that may lead to the elucidation of a neuropeptide's function. Knockdown (using RNA interference [RNAi]) or knockout of the neuropeptide (or receptor) gene and subsequent hypothesis-driven tests - based on the previously attained data - are the most often used approaches to fully functionally characterize a neuropeptide and its receptor. These approaches are especially powerful in the popular model organisms D. melanogaster and $C$. elegans, due to the existence of extensive genetic toolsets in both these invertebrates (including RNAi libraries and commercially available mutant or transgenic strains). In Drosophila for example, a reverse approach (Fig. 3) has led to the characterization of the Drosophila adipokinetic hormone and its effect on energy mobilization [232,233]. In $C$. elegans, examples of reverse approaches leading to the characterization of a peptide-receptor pair include the characterization of a gonadotropin-releasing hormone-like peptide as a regulator of reproduction [21] and a functional study linking a vasopressin/oxytocin-related peptide to associative learning [13]. In most invertebrates, it is also possible to directly inject a neuropeptide in order to study its effects on a chosen phenotype. For example, two approaches - knocking down the receptor through RNAi and direct injection of the peptide were recently used to functionally characterize the short neuropeptide $\mathrm{F}$ and its effect on feeding in the locust S. gregaria [234].

\section{Future perspectives}

Peptidergic signaling is evolutionarily ancient, since even the earliest animal taxa like Cnidaria have neuropeptides. Many invertebrate neuropeptides have conserved homologs in vertebrate lineages [206]. Further exploration of both the invertebrate and vertebrate neuropeptidomes and receptors will enable us to investigate the molecular evolution of peptidergic signaling units throughout evolution. Now we have reached a point where the neuropeptidome can be comprehensively charted on the genomic and peptidomic level within 
a time span of a few months. The ease of neuropeptidomic profiling increases with each sequenced genome and freely available neuropeptide spectral dataset. The neuropeptidome by itself contains functional information, mainly on the structural level. The exploration of more and more invertebrate genomes and neuropeptidomes will allow us to accurately determine the information-rich positions (constrained by evolution) in all neuropeptide classes, which will enhance the design and development of peptidomimetics. Hence, well-conserved peptides are prime candidates for receptor binding screens.

Differential neuropeptidomics is a first step in the functional characterization of newly found peptides. The experimental setup of differential peptidomics is closely related to gel-free quantitative approaches and has also reached the level where it can handle the complexity of the neuropeptidome very well (a selective neuropeptide extraction results in a less complex sample than a tryptic digest of proteins). It is therefore an ideal phenotype-centered screening method that can be scaled up for screening the possible roles of neuropeptides in developmental and physiological processes and invertebrate models of human diseases [11]. Differential peptidomics is complementary to other more labor-intensive phenotypic screening techniques such as neuropeptide-related knock-outs and RNAi screens. Such reverse functional characterization is as yet not applicable on a large scale, though it progressed cumulatively the last decades. Current ongoing projects aim to find as many invertebrate peptide-receptor pairs as possible. It is therefore expected that the importance of invertebrate model systems will even further increase during the next decade. More complete knowledge of the neuronal and endocrine regulation of insect physiology can provide necessary answers for the control of pest species and disease vectors, and stimulate the progression of invertebrate models of human diseases.

\section{Acknowledgements}

The authors acknowledge the Research Foundation Flanders (FWO-Vlaanderen, Belgium, G.04371.0N) and the European Research Council (ERC-2013-ADG-340318). Wouter De Haes is funded by the KU Leuven Research Fund. Elien Van Sinay and Liesbet Temmerman are research fellows of the FWO-Vlaanderen, Giel Detienne is funded by the Agency for Innovation by Science and Technology in Flanders (IWT). 


\section{References}

[1] A. Bogaerts, I. Beets, L. Schoofs, P. Verleyen, Antimicrobial peptides in Caenorhabditis elegans, Invertebr. Surviv. J. 7 (2010) 45-52.

[2] L. Zhao, W. Lu, Defensins in innate immunity., Curr. Opin. Hematol. 21 (2014) 37-42. doi:10.1097/MOH.0000000000000005.

[3] V. Hartenstein, The neuroendocrine system of invertebrates: a developmental and evolutionary perspective., J. Endocrinol. 190 (2006) 555-70. doi:10.1677/joe.1.06964.

[4] Y. Nyathi, B.M. Wilkinson, M.R. Pool, Co-translational targeting and translocation of proteins to the endoplasmic reticulum., Biochim. Biophys. Acta. 1833 (2013) 2392-402. doi:10.1016/j.bbamcr.2013.02.021.

[5] S.J. Husson, T. Janssen, G. Baggerman, B. Bogert, A.H. Kahn-Kirby, K. Ashrafi, et al., Impaired processing of FLP and NLP peptides in carboxypeptidase E (EGL-21)-deficient Caenorhabditis elegans as analyzed by mass spectrometry., J. Neurochem. 102 (2007) 246-60. doi:10.1111/j.1471-4159.2007.04474.x.

[6] C. Kienzle, J. von Blume, Secretory cargo sorting at the trans-Golgi network., Trends Cell Biol. (2014) 1-10. doi:10.1016/j.tcb.2014.04.007.

[7] C. Salio, L. Lossi, F. Ferrini, A. Merighi, Neuropeptides as synaptic transmitters., Cell Tissue Res. 326 (2006) 583-98. doi:10.1007/s00441-006-0268-3.

[8] L. Frooninckx, L. Van Rompay, L. Temmerman, E. Van Sinay, I. Beets, T. Janssen, et al., Neuropeptide GPCRs in C. elegans., Front. Endocrinol. (Lausanne). 3 (2012) 167. doi:10.3389/fendo.2012.00167.

[9] J. Caers, H. Verlinden, S. Zels, H.P. Vandersmissen, K. Vuerinckx, L. Schoofs, More than two decades of research on insect neuropeptide GPCRs: an overview., Front. Endocrinol. (Lausanne). 3 (2012) 151. doi:10.3389/fendo.2012.00151.

[10] K. Boonen, J.W. Creemers, L. Schoofs, Bioactive peptides, networks and systems biology., Bioessays. 31 (2009) 300-14. doi:10.1002/bies.200800055.

[11] S.D. Mhatre, B.E. Paddock, A.J. Saunders, D.R. Marenda, Invertebrate models of Alzheimer's disease., J. Alzheimers. Dis. 33 (2013) 3-16. doi:10.3233/JAD-2012-121204.

[12] K. Prüßing, A. Voigt, J.B. Schulz, Drosophila melanogaster as a model organism for Alzheimer's disease., Mol. Neurodegener. 8 (2013) 35. doi:10.1186/1750-1326-8-35.

[13] I. Beets, T. Janssen, E. Meelkop, L. Temmerman, N. Suetens, S. Rademakers, et al., Vasopressin/oxytocin-related signaling regulates gustatory associative learning in C. elegans., Science. 338 (2012) 543-5. doi:10.1126/science.1226860.

[14] J.L. Garrison, E.Z. Macosko, S. Bernstein, N. Pokala, D.R. Albrecht, C.I. Bargmann, Oxytocin/vasopressin-related peptides have an ancient role in reproductive behavior., Science. 338 (2012) 540-3. doi:10.1126/science.1226201. 
[15] H. Wang, K. Girskis, T. Janssen, J.P. Chan, K. Dasgupta, J.A. Knowles, et al., Neuropeptide secreted from a pacemaker activates neurons to control a rhythmic behavior., Curr. Biol. 23 (2013) 746-54. doi:10.1016/j.cub.2013.03.049.

[16] L.S. Nelson, M.L. Rosoff, C. Li, Disruption of a Neuropeptide Gene, flp-1, Causes Multiple Behavioral Defects in Caenorhabditis elegans, Science. 281 (1998) 1686-1690. doi:10.1126/science.281.5383.1686.

[17] C. Kaufmann, M.R. Brown, Regulation of carbohydrate metabolism and flight performance by a hypertrehalosaemic hormone in the mosquito Anopheles gambiae, J. Insect Physiol. 54 (2008) 367-377.

[18] Z. Hu, E.C.G. Pym, K. Babu, A.B. Vashlishan Murray, J.M. Kaplan, A neuropeptide-mediated stretch response links muscle contraction to changes in neurotransmitter release., Neuron. 71 (2011) 92-102. doi:10.1016/j.neuron.2011.04.021.

[19] S.-K. Park, C.D. Link, T.E. Johnson, Life-span extension by dietary restriction is mediated by NLP-7 signaling and coelomocyte endocytosis in C. elegans., FASEB J. 24 (2010) 383-92. doi:10.1096/fj.09-142984.

[20] M.J. Waterson, B.Y. Chung, Z.M. Harvanek, I. Ostojic, J. Alcedo, S.D. Pletcher, Water sensor ppk28 modulates Drosophila lifespan and physiology through AKH signaling., Proc. Natl. Acad. Sci. U. S. A. 111 (2014) 8137-42. doi:10.1073/pnas.1315461111.

[21] M. Lindemans, F. Liu, T. Janssen, S.J. Husson, I. Mertens, G. Gäde, et al., Adipokinetic hormone signaling through the gonadotropin-releasing hormone receptor modulates egg-laying in Caenorhabditis elegans., Proc. Natl. Acad. Sci. U. S. A. 106 (2009) 1642-1647. doi:10.1073/pnas.0809881106.

[22] H. Verlinden, L. Badisco, E. Marchal, P. Van Wielendaele, J. Vanden Broeck, Endocrinology of reproduction and phase transition in locusts., Gen. Comp. Endocrinol. 162 (2009) 79-92. doi:10.1016/j.ygcen.2008.11.016.

[23] P.H. Taghert, M.N. Nitabach, Peptide neuromodulation in invertebrate model systems., Neuron. 76 (2012) 82-97. doi:10.1016/j.neuron.2012.08.035.

[24] P. Schulz-Knappe, H.-D. Zucht, G. Heine, M. Jurgens, M. Schrader, Peptidomics: The comprehensive analysis of peptides in complex biological mixtures, Comb. Chem. High Throughput Screen. 4 (2001) 207-217.

[25] E. Clynen, G. Baggerman, D. Veelaert, a Cerstiaens, D. Van der Horst, L. Harthoorn, et al., Peptidomics of the pars intercerebralis-corpus cardiacum complex of the migratory locust, Locusta migratoria., Eur. J. Biochem. 268 (2001) 1929-39.

[26] M. Schrader, P. Schulz-Knappe, L.D. Fricker, Historical perspective of peptidomics, EuPA Open Proteomics. 3 (2014) 171-182. doi:10.1016/j.euprot.2014.02.014.

[27] K. Boonen, B. Landuyt, G. Baggerman, S.J. Husson, J. Huybrechts, L. Schoofs, Peptidomics: the integrated approach of MS, hyphenated techniques and bioinformatics for neuropeptide analysis., J. Sep. Sci. 31 (2008) 427-45. doi:10.1002/jssc.200700450. 
[28] C. Simó, A. Cifuentes, V. Kašička, Capillary electrophoresis-mass spectrometry for Peptide analysis: target-based approaches and proteomics/peptidomics strategies., Methods Mol. Biol. 984 (2013) 139-51. doi:10.1007/978-1-62703-296-4_11.

[29] G. Baggerman, P. Verleyen, E. Clynen, J. Huybrechts, A. De Loof, L. Schoofs, Peptidomics., J. Chromatogr. B. Analyt. Technol. Biomed. Life Sci. 803 (2004) 3-16.

doi:10.1016/j.jchromb.2003.07.019.

[30] M. Svensson, K. Skold, A. Nilsson, M. Falth, P. Svenningsson, P. Andren, Neuropeptidomics: expanding proteomics downwards, Biochem. Soc. Trans. 35 (2007) 588-93.

[31] J.R. Yates, D. Cociorva, L. Liao, V. Zabrouskov, Performance of a linear ion trap-Orbitrap hybrid for peptide analysis., Anal. Chem. 78 (2006) 493-500. doi:10.1021/ac0514624.

[32] E. Hayakawa, G. Menschaert, P.-J. De Bock, W. Luyten, K. Gevaert, G. Baggerman, et al., Improving the identification rate of endogenous peptides using electron transfer dissociation and collision-induced dissociation., J. Proteome Res. 12 (2013) 5410-21. doi:10.1021/pr400446z.

[33] K. Sasaki, T. Osaki, N. Minamino, Large-scale identification of endogenous secretory peptides using electron transfer dissociation mass spectrometry., Mol. Cell. Proteomics. 12 (2013) 7009. doi:10.1074/mcp.M112.017400.

[34] L. Martens, H. Hermjakob, P. Jones, M. Adamski, C. Taylor, D. States, et al., PRIDE: the proteomics identifications database., Proteomics. 5 (2005) 3537-45. doi:10.1002/pmic.200401303.

[35] M. Fälth, K. Sköld, M. Norrman, M. Svensson, D. Fenyö, P.E. Andren, SwePep, a database designed for endogenous peptides and mass spectrometry., Mol. Cell. Proteomics. 5 (2006) 998-1005. doi:10.1074/mcp.M500401-MCP200.

[36] A.A. Zamyatnin, A.S. Borchikov, M.G. Vladimirov, O.L. Voronina, The EROP-Moscow oligopeptide database., Nucleic Acids Res. 34 (2006) D261-6. doi:10.1093/nar/gkj008.

[37] F. Liu, G. Baggerman, L. Schoofs, G. Wets, The construction of a bioactive peptide database in Metazoa., J. Proteome Res. 7 (2008) 4119-31. doi:10.1021/pr800037n.

[38] N. Minamino, J. Tanaka, H. Kuwahara, T. Kihara, Y. Satomi, M. Matsubae, et al., Determination of endogenous peptides in the porcine brain: possible construction of Peptidome, a fact database for endogenous peptides, J. Chromatogr. B. 792 (2003) 33-48. doi:10.1016/S1570-0232(03)00280-0.

[39] K. Sköld, M. Svensson, A. Kaplan, L. Björkesten, J. Aström, P.E. Andren, A neuroproteomic approach to targeting neuropeptides in the brain., Proteomics. 2 (2002) 447-54. doi:10.1002/1615-9861(200204)2:4<447::AID-PROT447>3.0.CO;2-A.

[40] G. Baggerman, A. Cerstiaens, A. De Loof, L. Schoofs, Peptidomics of the larval Drosophila melanogaster central nervous system., J. Biol. Chem. 277 (2002) 40368-74. doi:10.1074/jbc.M206257200.

[41] S.J. Husson, E. Clynen, G. Baggerman, A. De Loof, L. Schoofs, Discovering neuropeptides in Caenorhabditis elegans by two dimensional liquid chromatography and mass spectrometry, Biochem. Biophys. Res. Commun. 335 (2005) 76-86. doi:10.1016/j.bbrc.2005.07.044. 
[42] S.J. Husson, E. Clynen, K. Boonen, T. Janssen, M. Lindemans, G. Baggerman, et al., Approaches to identify endogenous peptides in the soil nematode Caenorhabditis elegans., Methods Mol. Biol. 615 (2010) 29-47. doi:10.1007/978-1-60761-535-4_3.

[43] S.W. Taylor, S.E. Nikoulina, N.L. Andon, C. Lowe, Peptidomic Pro fi ling of Secreted Products from Pancreatic Islet Culture Results in a Higher Yield of Full-length Peptide Hormones than Found using Cell Lysis Procedures, (2013).

[44] K. Sasaki, Y. Satomi, T. Takao, N. Minamino, Snapshot peptidomics of the regulated secretory pathway., Mol. Cell. Proteomics. 8 (2009) 1638-47. doi:10.1074/mcp.M900044-MCP200.

[45] R. Predel, S. Neupert, W. Huetteroth, J. Kahnt, D. Waidelich, S. Roth, Peptidomics-based phylogeny and biogeography of Mantophasmatodea (Hexapoda)., Syst. Biol. 61 (2012) 609629. doi:10.1093/sysbio/sys003.

[46] R. Predel, W.K. Russell, D.H. Russell, J. Lopez, J. Esquivel, R.J. Nachman, Comparative peptidomics of four related hemipteran species: pyrokinins, myosuppressin, corazonin, adipokinetic hormone, sNPF, and periviscerokinins., Peptides. 29 (2008) 162-7. doi:10.1016/j.peptides.2007.08.034.

[47] C. Wegener, S. Neupert, R. Predel, Direct MALDI-TOF mass spectrometric peptide profiling of neuroendocrine tissue of Drosophila., Methods Mol. Biol. 615 (2010) 117-27.

[48] S. Neupert, S.S. Rubakhin, J. V Sweedler, Targeted single-cell microchemical analysis: MSbased peptidomics of individual paraformaldehyde-fixed and immunolabeled neurons., Chem. Biol. 19 (2012) 1010-9. doi:10.1016/j.chembiol.2012.05.023.

[49] B.R. Southey, J. V Sweedler, S.L. Rodriguez-Zas, A python analytical pipeline to identify prohormone precursors and predict prohormone cleavage sites., Front. Neuroinform. 2 (2008) 7. doi:10.3389/neuro.11.007.2008.

[50] F. Liu, G. Baggerman, W. D’Hertog, P. Verleyen, L. Schoofs, G. Wets, In silico identification of new secretory peptide genes in Drosophila melanogaster., Mol. Cell. Proteomics. 5 (2006) 510-22. doi:10.1074/mcp.M400114-MCP200.

[51] B.R. Southey, A. Amare, T.A. Zimmerman, S.L. Rodriguez-Zas, J. V Sweedler, NeuroPred: a tool to predict cleavage sites in neuropeptide precursors and provide the masses of the resulting peptides., Nucleic Acids Res. 34 (2006) W267-72. doi:10.1093/nar/gkl161.

[52] D.N. Perkins, D.J. Pappin, D.M. Creasy, J.S. Cottrell, Probability-based protein identification by searching sequence databases using mass spectrometry data., Electrophoresis. 20 (1999) 3551-67. doi:10.1002/(SICI)1522-2683(19991201)20:18<3551::AID-ELPS3551>3.0.CO;2-2.

[53] J.K. Eng, A.L. McCormack, J.R. Yates, An approach to correlate tandem mass spectral data of peptides with amino acid sequences in a protein database., J. Am. Soc. Mass Spectrom. 5 (1994) 976-89. doi:10.1016/1044-0305(94)80016-2.

[54] R. Craig, R.C. Beavis, TANDEM: matching proteins with tandem mass spectra., Bioinformatics. 20 (2004) 1466-7. doi:10.1093/bioinformatics/bth092.

[55] M. Brosch, L. Yu, T. Hubbard, J. Choudhary, Accurate and sensitive peptide identification with Mascot Percolator., J. Proteome Res. 8 (2009) 3176-81. doi:10.1021/pr800982s. 
[56] K. Helsens, E. Timmerman, J. Vandekerckhove, K. Gevaert, L. Martens, Peptizer, a tool for assessing false positive peptide identifications and manually validating selected results., Mol. Cell. Proteomics. 7 (2008) 2364-72. doi:10.1074/mcp.M800082-MCP200.

[57] G. Menschaert, T.T.M. Vandekerckhove, B. Landuyt, E. Hayakawa, L. Schoofs, W. Luyten, et al., Spectral clustering in peptidomics studies helps to unravel modification profile of biologically active peptides and enhances peptide identification rate., Proteomics. 9 (2009) 4381-8. doi:10.1002/pmic.200900248.

[58] A.B. Hummon, A. Amare, J. V Sweedler, Discovering new invertebrate neuropeptides using mass spectrometry., Mass Spectrom. Rev. 25 (2005) 77-98. doi:10.1002/mas.20055.

[59] G. Menschaert, T.T.M. Vandekerckhove, G. Baggerman, B. Landuyt, J. V Sweedler, L. Schoofs, et al., A Hybrid, de Novo Based, Genome-Wide Database Search Approach Applied to the Sea Urchin Neuropeptidome research articles, (2010) 990-996.

[60] J.L. Jarecki, B.L. Frey, L.M. Smith, A.O. Stretton, Discovery of neuropeptides in the nematode Ascaris suum by database mining and tandem mass spectrometry., J. Proteome Res. 10 (2011) 3098-106. doi:10.1021/pr2001176.

[61] T. Kawada, M. Ogasawara, T. Sekiguchi, M. Aoyama, K. Hotta, K. Oka, et al., Peptidomic analysis of the central nervous system of the protochordate, Ciona intestinalis: homologs and prototypes of vertebrate peptides and novel peptides., Endocrinology. 152 (2011) 2416-27. doi:10.1210/en.2010-1348.

[62] R. Predel, G. Gerd, Peptidomics of neurohemal organs from species of the cockroach family Blattidae: how do neuropeptides of closely related species differ ?, 26 (2005) 3-9. doi:10.1016/j.peptides.2004.10.010.

[63] B. Li, R. Predel, S. Neupert, F. Hauser, Y. Tanaka, G. Cazzamali, et al., Genomics, transcriptomics, and peptidomics of neuropeptides and protein hormones in the red flour beetle Tribolium castaneum., Genome Res. 18 (2008) 113-22. doi:10.1101/gr.6714008.

[64] R. Predel, S. Neupert, S.F. Garczynski, J.W. Crim, R. Mark, W.K. Russell, et al., Neuropeptidomics of the mosquito Aedes aegypti, J. Proteome Res. 9 (2010) 2006-2015. doi:10.1021/pr901187p.Neuropeptidomics.

[65] K.P. Siju, A. Reifenrath, H. Scheiblich, S. Neupert, R. Predel, B.S. Hansson, et al., Neuropeptides in the antennal lobe of the yellow fever mosquito, Aedes aegypti., J. Comp. Neurol. 522 (2014) 592-608. doi:10.1002/cne.23434.

[66] J. Zoephel, W. Reiher, K.-H. Rexer, J. Kahnt, C. Wegener, Peptidomics of the agriculturally damaging larval stage of the cabbage root fly Delia radicum (Diptera: Anthomyiidae)., PLoS One. 7 (2012) e41543. doi:10.1371/journal.pone.0041543.

[67] R. Predel, C. Wegener, W.K. Russell, S.E. Tichy, D.H. Russell, R.J. Nachman, Peptidomics of CNS-associated neurohemal systems of adult Drosophila melanogaster: a mass spectrometric survey of peptides from individual flies., J. Comp. Neurol. 474 (2004) 379-92. doi:10.1002/cne.20145.

[68] J. Caers, K. Peymen, V. Broeckx, J. Van Den Abbeele, G. Gäde, H. Marco, et al., Identification and characterization of neuropeptidergic signaling systems of the tsetse fly, Glossina morsitans, in: Int. Congr. Comp. Endocrinol. Ed. 17, Barcelona, Spain , 15-19 July 2013, 2013. 
[69] P. Verleyen, J. Huybrechts, F. Sas, E. Clynen, G. Baggerman, A. De Loof, et al., Neuropeptidomics of the grey flesh fly, Neobellieria bullata., Biochem. Biophys. Res. Commun. 316 (2004) 763-70. doi:10.1016/j.bbrc.2004.02.115.

[70] J. Huybrechts, J. Bonhomme, S. Minoli, N. Prunier-Leterme, A. Dombrovsky, M. AbdelLatief, et al., Neuropeptide and neurohormone precursors in the pea aphid, Acyrthosiphon pisum., Insect Mol. Biol. 19 Suppl 2 (2010) 87-95. doi:10.1111/j.1365-2583.2009.00951.x.

[71] M. Sterkel, H. Urlaub, R. Rivera-Pomar, S. Ons, Functional proteomics of neuropeptidome dynamics during the feeding process of Rhodnius prolixus., J. Proteome Res. 10 (2011) 336371. doi:10.1021/pr2001012.

[72] A. Brockmann, S.P. Annangudi, T. a Richmond, S. a Ament, F. Xie, B.R. Southey, et al., Quantitative peptidomics reveal brain peptide signatures of behavior., Proc. Natl. Acad. Sci. U. S. A. 106 (2009) 2383-8. doi:10.1073/pnas.0813021106.

[73] B. Boerjan, D. Cardoen, A. Bogaerts, B. Landuyt, L. Schoofs, P. Verleyen, Mass spectrometric profiling of (neuro)-peptides in the worker honeybee, Apis mellifera., Neuropharmacology. 58 (2010) 248-58. doi:10.1016/j.neuropharm.2009.06.026.

[74] F. Hauser, S. Neupert, M. Williamson, R. Predel, Y. Tanaka, C.J.P. Grimmelikhuijzen, Genomics and Peptidomics of Neuropeptides and Protein Hormones Present in the Parasitic Wasp Nasonia vitripennis, J. Proteome Res. (2010) 5296-5310.

[75] X. Liu, X. Ning, Y. Zhang, W. Chen, Z. Zhao, Q. Zhang, Peptidomic Analysis of the Brain and Corpora Cardiaca-Corpora Allata Complex in the Bombyx mori., Int. J. Pept. 2012 (2012) 640359. doi:10.1155/2012/640359.

[76] J. Huybrechts, P. Verleyen, L. Schoofs, Mass spectrometric analysis of head ganglia and neuroendocrine tissue of larval Galleria mellonella (Arthropoda, Insecta)., J. Mass Spectrom. 40 (2005) 271-6. doi:10.1002/jms.835.

[77] E. Clynen, G. Baggerman, J. Huybrechts, L. Vanden Bosch, A. De Loof, L. Schoofs, Peptidomics of the locust corpora allata: identification of novel pyrokinins (-FXPRLamides)., Peptides. 24 (2003) 1493-500.

[78] G. Menschaert, E. Hayakawa, L. Schoofs, W. Van Criekinge, G. Baggerman, Spectral Clustering in Peptidomics Studies Allows Homology Searching and Modification Profiling: HomClus, a Versatile Tool., J. Proteome Res. 11 (2012) 2774-85. doi:10.1021/pr201114m.

[79] F. Xiang, H. Ye, R. Chen, Q. Fu, L. Li, N,N-Dimethyl leucines as novel isobaric tandem mass tags for quantitative proteomics and peptidomics, Anal. Chem. 82 (2010) 2817-2825. doi:10.1021/ac902778d.N.

[80] J. Wang, Y. Zhang, F. Xiang, Z. Zhang, L. Li, Combining capillary electrophoresis matrixassisted laser desorption/ionization mass spectrometry and stable isotopic labeling techniques for comparative crustacean peptidomics., J. Chromatogr. A. 1217 (2010) 4463-70. doi:10.1016/j.chroma.2010.02.084.

[81] Z. Zhang, S. Jiang, L. Li, Semi-automated liquid chromatography-mass spectrometric imaging platform for enhanced detection and improved data analysis of complex peptides., J. Chromatogr. A. 1293 (2013) 44-50. doi:10.1016/j.chroma.2013.03.042. 
[82] Z. Zhang, C. Jia, L. Li, Neuropeptide analysis with liquid chromatography-capillary electrophoresis-mass spectrometric imaging., J. Sep. Sci. 35 (2012) 1779-84. doi:10.1002/jssc.201200051.

[83] C. Jia, C.B. Lietz, H. Ye, L. Hui, Q. Yu, S. Yoo, et al., A multi-scale strategy for discovery of novel endogenous neuropeptides in the crustacean nervous system., J. Proteomics. 91 (2013) 112. doi:10.1016/j.jprot.2013.06.021.

[84] J. Huybrechts, M.P. Nusbaum, L. Vanden Bosch, G. Baggerman, A. De Loof, L. Schoofs, Neuropeptidomic analysis of the brain and thoracic ganglion from the Jonah crab, Cancer borealis., Biochem. Biophys. Res. Commun. 308 (2003) 535-44.

[85] J.J. Schmidt, S. Mcilwain, D. Page, A.E. Christie, L. Li, Combining MALDI-FTMS and Bioinformatics for Rapid Peptidomic Comparisons, J. Proteome Res. 7 (2008) 887-896. doi: 10.1021/pr070390p.

[86] H. Dircksen, S. Neupert, R. Predel, P. Verleyen, J. Huybrechts, J. Strauss, et al., Genomics, transcriptomics, and peptidomics of Daphnia pulex neuropeptides and protein hormones., J. Proteome Res. 10 (2011) 4478-504. doi:10.1021/pr200284e.

[87] E. V Romanova, S.S. Rubakhin, J. V Sweedler, One-step sampling, extraction, and storage protocol for peptidomics using dihydroxybenzoic Acid., Anal. Chem. 80 (2008) 3379-86. doi:10.1021/ac7026047.

[88] Z. El Filali, J. Van Minnen, W.K. Liu, A.B. Smit, K.W. Li, Peptidomics Analysis of Neuropeptides Involved in Copulatory Behavior of the Mollusk Lymnaea stagnalis, J. Proteome Res. 5 (2006) 1611-1617.

[89] C.R. Jiménez, S. Spijker, S. de Schipper, J.C. Lodder, C.K. Janse, W.P.M. Geraerts, et al., Peptidomics of a single identified neuron reveals diversity of multiple neuropeptides with convergent actions on cellular excitability., J. Neurosci. 26 (2006) 518-29. doi:10.1523/JNEUROSCI.2566-05.2006.

[90] A. Frank, P. Pevzner, PepNovo: de novo peptide sequencing via probabilistic network modeling., Anal. Chem. 77 (2005) 964-73.

[91] B. Ma, K. Zhang, C. Hendrie, C. Liang, M. Li, A. Doherty-Kirby, et al., PEAKS: powerful software for peptide de novo sequencing by tandem mass spectrometry., Rapid Commun. Mass Spectrom. 17 (2003) 2337-42. doi:10.1002/rcm.1196.

[92] D.L. Tabb, Z.-Q. Ma, D.B. Martin, A.-J.L. Ham, M.C. Chambers, DirecTag: accurate sequence tags from peptide MS/MS through statistical scoring., J. Proteome Res. 7 (2008) 3838-46. doi:10.1021/pr800154p.

[93] E.P. Costa, G. Menschaert, W. Luyten, K. De Grave, J. Ramon, PIUS: peptide identification by unbiased search., Bioinformatics. 29 (2013) 1913-4. doi:10.1093/bioinformatics/btt298.

[94] S. Kim, N. Gupta, N. Bandeira, P.A. Pevzner, Spectral dictionaries: Integrating de novo peptide sequencing with database search of tandem mass spectra., Mol. Cell. Proteomics. 8 (2009) 5369. doi:10.1074/mcp.M800103-MCP200. 
[95] J. Zhang, L. Xin, B. Shan, W. Chen, M. Xie, D. Yuen, et al., PEAKS DB: de novo sequencing assisted database search for sensitive and accurate peptide identification., Mol. Cell. Proteomics. 11 (2012) M111.010587. doi:10.1074/mcp.M111.010587.

[96] H. Lam, E.W. Deutsch, J.S. Eddes, J.K. Eng, N. King, S.E. Stein, et al., Development and validation of a spectral library searching method for peptide identification from MS/MS., Proteomics. 7 (2007) 655-67. doi:10.1002/pmic.200600625.

[97] C.-Y. Yen, K. Meyer-Arendt, B. Eichelberger, S. Sun, S. Houel, W.M. Old, et al., A simulated MS/MS library for spectrum-to-spectrum searching in large scale identification of proteins., Mol. Cell. Proteomics. 8 (2009) 857-69. doi:10.1074/mcp.M800384-MCP200.

[98] B. Frewen, M.J. MacCoss, Using BiblioSpec for creating and searching tandem MS peptide libraries., Curr. Protoc. Bioinformatics. Chapter 13 (2007) Unit 13.7. doi:10.1002/0471250953.bi1307s20.

[99] G. Menschaert, T.T.M. Vandekerckhove, G. Baggerman, L. Schoofs, W. Luyten, W. Van Criekinge, Peptidomics coming of age: a review of contributions from a bioinformatics angle., J. Proteome Res. 9 (2010) 2051-61. doi:10.1021/pr900929m.

[100] J. Huybrechts, A. De Loof, L. Schoofs, Diapausing Colorado potato beetles are devoid of short neuropeptide F I and II., Biochem. Biophys. Res. Commun. 317 (2004) 909-16. doi:10.1016/j.bbrc.2004.03.136.

[101] S.J. Husson, B. Landuyt, T. Nys, G. Baggerman, K. Boonen, E. Clynen, et al., Comparative peptidomics of Caenorhabditis elegans versus $C$. briggsae by LC-MALDI-TOF MS., Peptides. 30 (2009) 449-57. doi:10.1016/j.peptides.2008.07.021.

[102] S. Uttenweiler-Joseph, M. Moniatte, M. Lagueux, A. Van Dorsselaer, J.A. Hoffmann, P. Bulet, Differential display of peptides induced during the immune response of Drosophila: a matrixassisted laser desorption ionization time-of-flight mass spectrometry study., Proc. Natl. Acad. Sci. U. S. A. 95 (1998) 11342-7.

[103] F. Levy, D. Rabel, M. Charlet, P. Bulet, J. a Hoffmann, L. Ehret-Sabatier, Peptidomic and proteomic analyses of the systemic immune response of Drosophila., Biochimie. 86 (2004) 607-16. doi:10.1016/j.biochi.2004.07.007.

[104] P. Verleyen, G. Baggerman, W. D’Hertog, E. Vierstraete, S.J. Husson, L. Schoofs, Identification of new immune induced molecules in the haemolymph of Drosophila melanogaster by 2D-nanoLC MS/MS., J. Insect Physiol. 52 (2006) 379-88. doi:10.1016/j.jinsphys.2005.12.007.

[105] C. Wegener, T. Reinl, L. Jänsch, R. Predel, Direct mass spectrometric peptide profiling and fragmentation of larval peptide hormone release sites in Drosophila melanogaster reveals tagma-specific peptide expression and differential processing., J. Neurochem. 96 (2006) 136274. doi:10.1111/j.1471-4159.2005.03634.x.

[106] E. Clynen, D. Stubbe, A. De Loof, L. Schoofs, Peptide differential display: a novel approach for phase transition in locusts., Comp. Biochem. Physiol. B. Biochem. Mol. Biol. 132 (2002) $107-15$.

[107] M.M. Rahman, a Vandingenen, M. Begum, M. Breuer, A. De Loof, R. Huybrechts, Search for phase specific genes in the brain of desert locust, Schistocerca gregaria (Orthoptera: 
Acrididae) by differential display polymerase chain reaction., Comp. Biochem. Physiol. A. Mol. Integr. Physiol. 135 (2003) 221-8.

[108] S.J. Husson, E. Clynen, G. Baggerman, T. Janssen, L. Schoofs, Defective processing of neuropeptide precursors in Caenorhabditis elegans lacking proprotein convertase 2 (KPC2/EGL-3): mutant analysis by mass spectrometry, J. Neurochem. 98 (2006) 1999-2012. doi:10.1111/j.1471-4159.2006.04014.x.

[109] P. Verleyen, J. Huybrechts, G. Baggerman, A. Van Lommel, A. De Loof, L. Schoofs, SIFamide is a highly conserved neuropeptide: a comparative study in different insect species., Biochem. Biophys. Res. Commun. 320 (2004) 334-41. doi:10.1016/j.bbrc.2004.05.173.

[110] W.-T. Lin, K.-P. Wu, W.-N. Hung, Y.-H. Yian, Y.-R. Chen, Y.-J. Chen, et al., MassTRAQ: a Fully Automated Tool for iTRAQ-labeled Protein Quantification, in: 2005 IEEE Comput. Syst. Bioinforma. Conf. - Work., IEEE, n.d.: pp. 157-158.

[111] H. Weisser, S. Nahnsen, J. Grossmann, L. Nilse, A. Quandt, H. Brauer, et al., An automated pipeline for high-throughput label-free quantitative proteomics., J. Proteome Res. 12 (2013) 1628-44. doi:10.1021/pr300992u.

[112] F.-Y. Che, L.D. Fricker, Quantitative peptidomics of mouse pituitary: comparison of different stable isotopic tags., J. Mass Spectrom. 40 (2005) 238-49. doi:10.1002/jms.743.

[113] S. Ong, B. Blagoev, I. Kratchmarova, D.B. Kristensen, H. Steen, A. Pandey, et al., Stable Isotope Labeling by Amino Acids in Cell Culture, SILAC, as a Simple and Accurate Approach to Expression Proteomics, Mol. Cell. Proteomics. 1 (2002) 376-386. doi:10.1074/mcp.M200025-MCP200.

[114] M. Larance, A.P. Bailly, E. Pourkarimi, R.T. Hay, S. Coulthurst, D.P. Xirodimas, et al., Stable Isotope Labeling with Amino acids in Nematodes, Nat. Methods. 8 (2011) 849-851. doi:10.1038/nmeth.1679.Stable.

[115] M.D. Sury, J.-X. Chen, M. Selbach, The SILAC fly allows for accurate protein quantification in vivo., Mol. Cell. Proteomics. 9 (2010) 2173-83. doi:10.1074/mcp.M110.000323.

[116] S.S. Rubakhin, J. V Sweedler, Quantitative measurements of cell-cell signaling peptides with single-cell MALDI MS., Anal. Chem. 80 (2008) 7128-36. doi:10.1021/ac8010389.

[117] S.P. Gygi, B. Rist, S. Gerber, F. Turecek, M. Gelb, R. Aebersold, Quantitative analysis of complex protein mixtures using isotope-coded affinity tags, Nat. Biotechnol. 17 (1999) 994999.

[118] A. Thompson, J. Schäfer, K. Kuhn, S. Kienle, J. Schwarz, G. Schmidt, et al., Tandem mass tags: a novel quantification strategy for comparative analysis of complex protein mixtures by MS/MS., Anal. Chem. 75 (2003) 1895-904.

[119] P.L. Ross, Y.N. Huang, J.N. Marchese, B. Williamson, K. Parker, S. Hattan, et al., Multiplexed protein quantitation in Saccharomyces cerevisiae using amine-reactive isobaric tagging reagents., Mol. Cell. Proteomics. 3 (2004) 1154-69. doi:10.1074/mcp.M400129-MCP200.

[120] B.R. Southey, J.E. Lee, L. Zamdborg, N. Atkins, J.W. Mitchell, M. Li, et al., Comparing labelfree quantitative peptidomics approaches to characterize diurnal variation of peptides in the rat suprachiasmatic nucleus., Anal. Chem. 86 (2014) 443-52. doi:10.1021/ac4023378. 
[121] N.M. Griffin, J. Yu, F. Long, P. Oh, S. Shore, Y. Li, et al., Label-free, normalized quantification of complex mass spectrometry data for proteomic analysis., Nat. Biotechnol. 28 (2010) 83-9. doi:10.1038/nbt.1592.

[122] E. V Romanova, S.E. Dowd, J. V Sweedler, Quantitation of endogenous peptides using mass spectrometry based methods., Curr. Opin. Chem. Biol. 17 (2013) 801-8. doi:10.1016/j.cbpa.2013.05.030.

[123] R. Chen, L. Hui, S.S. Cape, J. Wang, L. Li, Comparative Neuropeptidomic Analysis of Food Intake via a Multi-faceted Mass Spectrometric Approach., ACS Chem. Neurosci. 1 (2010) 204-214. doi:10.1021/cn900028s.

[124] G.A. Kleemann, C.T. Murphy, The endocrine regulation of aging in Caenorhabditis elegans., Mol. Cell. Endocrinol. 299 (2009) 51-7. doi:10.1016/j.mce.2008.10.048.

[125] S.H. Panowski, A. Dillin, Signals of youth: endocrine regulation of aging in Caenorhabditis elegans., Trends Endocrinol. Metab. 20 (2009) 259-264. doi:10.1016/j.tem.2009.03.006.

[126] G. Henderson, A.T. McKnight, The orphan opioid receptor and its endogenous ligand-nociceptin/orphanin FQ., Trends Pharmacol. Sci. 18 (1997) 293-300.

[127] A.D. Howard, G. McAllister, S.D. Feighner, Q. Liu, R.P. Nargund, L.H. Van der Ploeg, et al., Orphan G-protein-coupled receptors and natural ligand discovery., Trends Pharmacol. Sci. 22 (2001) 132-40.

[128] T. Meeusen, I. Mertens, A. De Loof, L. Schoofs, G Protein-Coupled Receptors in Invertebrates: A State of the Art, Int. Rev. Cytol. 230 (2003) 189-261. doi:10.1016/S00747696(03)30004-X.

[129] D.R. Nässel, A.M.E. Winther, Drosophila neuropeptides in regulation of physiology and behavior., Prog. Neurobiol. 92 (2010) 42-104. doi:10.1016/j.pneurobio.2010.04.010.

[130] T. Janssen, E. Meelkop, M. Lindemans, K. Verstraelen, S.J. Husson, L. Temmerman, et al., Discovery of a cholecystokinin-gastrin-like signaling system in nematodes., Endocrinology. 149 (2008) 2826-39. doi:10.1210/en.2007-1772.

[131] N. Ringstad, H.R. Horvitz, FMRFamide neuropeptides and acetylcholine synergistically inhibit egg-laying by C. elegans., Nat. Neurosci. 11 (2008) 1168-76. doi:10.1038/nn.2186.

[132] I. Mertens, T. Meeusen, T. Janssen, R. Nachman, L. Schoofs, Molecular characterization of two G protein-coupled receptor splice variants as FLP2 receptors in Caenorhabditis elegans., Biochem. Biophys. Res. Commun. 330 (2005) 967-74. doi:10.1016/j.bbrc.2005.03.071.

[133] I. Mertens, A. Vandingenen, E. Clynen, R.J. Nachman, A. De Loof, L. Schoofs, Characterization of an RFamide-related peptide orphan GPCR in C. elegans., Ann. N. Y. Acad. Sci. 1040 (2005) 410-412. doi:10.1196/annals.1327.076.

[134] M. Lindemans, T. Janssen, S.J. Husson, E. Meelkop, L. Temmerman, E. Clynen, et al., A neuromedin-pyrokinin-like neuropeptide signaling system in Caenorhabditis elegans., Biochem. Biophys. Res. Commun. 379 (2009) 760-4. doi:10.1016/j.bbrc.2008.12.121.

[135] T.M. Kubiak, M.J. Larsen, S.C. Nulf, M.R. Zantello, K.J. Burton, J.W. Bowman, et al., Differential activation of "social" and "solitary" variants of the Caenorhabditis elegans G 
protein-coupled receptor NPR-1 by its cognate ligand AF9., J. Biol. Chem. 278 (2003) 337249. doi:10.1074/jbc.M304861200.

[136] D.E. Lowery, G.G. Timothy, T.M. Kubiak, M.J. Larsen, G protein-coupled receptor-like receptors and modulators thereof, 6632621, 2003.

[137] I. Mertens, I. Clinckspoor, T. Janssen, R. Nachman, L. Schoofs, FMRFamide related peptide ligands activate the Caenorhabditis elegans orphan GPCR Y59H11AL.1., Peptides. 27 (2006) 1291-6. doi:10.1016/j.peptides.2005.11.017.

[138] T.M. Kubiak, M.J. Larsen, M.R. Zantello, J.W. Bowman, S.C. Nulf, D.E. Lowery, Functional annotation of the putative orphan Caenorhabditis elegans G-protein-coupled receptor C10C6.2 as a FLP15 peptide receptor., J. Biol. Chem. 278 (2003) 42115-20. doi:10.1074/jbc.M304056200.

[139] M. Cohen, V. Reale, B. Olofsson, A. Knights, P. Evans, M. de Bono, Coordinated regulation of foraging and metabolism in C. elegans by RFamide neuropeptide signaling., Cell Metab. 9 (2009) 375-85. doi:10.1016/j.cmet.2009.02.003.

[140] T.M. Kubiak, M.J. Larsen, J.W. Bowman, T.G. Geary, D.E. Lowery, FMRFamide-like peptides encoded on the $f l p-18$ precursor gene activate two isoforms of the orphan Caenorhabditis elegans G-protein-coupled receptor Y58G8A.4 heterologously expressed in mammalian cells., Biopolymers. 90 (2008) 339-48. doi:10.1002/bip.20850.

[141] T. Janssen, S.J. Husson, M. Lindemans, I. Mertens, S. Rademakers, K. Ver Donck, et al., Functional characterization of three $\mathrm{G}$ protein-coupled receptors for pigment dispersing factors in Caenorhabditis elegans., J. Biol. Chem. 283 (2008) 15241-9. doi:10.1074/jbc.M709060200.

[142] F. Staubli, T.J.D. Jorgensen, G. Cazzamali, M. Williamson, C. Lenz, L. Sondergaard, et al., Molecular identification of the insect adipokinetic hormone receptors., Proc. Natl. Acad. Sci. U. S. A. 99 (2002) 3446-51. doi:10.1073/pnas.052556499.

[143] N. Birgül, C. Weise, H.J. Kreienkamp, D. Richter, Reverse physiology in drosophila: identification of a novel allatostatin-like neuropeptide and its cognate receptor structurally related to the mammalian somatostatin/galanin/opioid receptor family., EMBO J. 18 (1999) 5892-900. doi:10.1093/emboj/18.21.5892.

[144] M.J. Larsen, K.J. Burton, M.R. Zantello, V.G. Smith, D.L. Lowery, T.M. Kubiak, Type A allatostatins from Drosophila melanogaster and Diplotera puncata activate two Drosophila allatostatin receptors, DAR-1 and DAR-2, expressed in CHO cells., Biochem. Biophys. Res. Commun. 286 (2001) 895-901. doi:10.1006/bbrc.2001.5476.

[145] C. Lenz, M. Williamson, G.N. Hansen, C.J. Grimmelikhuijzen, Identification of four Drosophila allatostatins as the cognate ligands for the Drosophila orphan receptor DAR-2., Biochem. Biophys. Res. Commun. 286 (2001) 1117-22. doi:10.1006/bbrc.2001.5475.

[146] H.-J. Kreienkamp, H.J. Larusson, I. Witte, T. Roeder, N. Birgul, H.-H. Honck, et al., Functional annotation of two orphan G-protein-coupled receptors, Drostar1 and -2, from Drosophila melanogaster and their ligands by reverse pharmacology., J. Biol. Chem. 277 (2002) 39937-43. doi:10.1074/jbc.M206931200.

[147] A. Iversen, G. Cazzamali, M. Williamson, F. Hauser, C.J.P. Grimmelikhuijzen, Molecular cloning and functional expression of a Drosophila receptor for the neuropeptides capa-1 and 2., Biochem. Biophys. Res. Commun. 299 (2002) 628-33. 
[148] K.K. Hansen, F. Hauser, M. Williamson, S.B. Weber, C.J.P. Grimmelikhuijzen, The Drosophila genes CG14593 and CG30106 code for G-protein-coupled receptors specifically activated by the neuropeptides CCHamide-1 and CCHamide-2., Biochem. Biophys. Res. Commun. 404 (2011) 184-9. doi:10.1016/j.bbrc.2010.11.089.

[149] G. Cazzamali, N. Saxild, C. Grimmelikhuijzen, Molecular cloning and functional expression of a Drosophila corazonin receptor., Biochem. Biophys. Res. Commun. 298 (2002) 31-6.

[150] G. Cazzamali, C.J.P. Grimmelikhuijzen, Molecular cloning and functional expression of the first insect FMRFamide receptor., Proc. Natl. Acad. Sci. U. S. A. 99 (2002) 12073-8. doi:10.1073/pnas.192442799.

[151] K. Egerod, E. Reynisson, F. Hauser, G. Cazzamali, M. Williamson, C.J.P. Grimmelikhuijzen, Molecular cloning and functional expression of the first two specific insect myosuppressin receptors., Proc. Natl. Acad. Sci. U. S. A. 100 (2003) 9808-13. doi:10.1073/pnas.1632197100.

[152] G. Cazzamali, M. Torp, F. Hauser, M. Williamson, C.J.P. Grimmelikhuijzen, The Drosophila gene CG9918 codes for a pyrokinin-1 receptor., Biochem. Biophys. Res. Commun. 335 (2005) 14-9. doi:10.1016/j.bbrc.2005.07.038.

[153] C. Rosenkilde, G. Cazzamali, M. Williamson, F. Hauser, L. Søndergaard, R. DeLotto, et al., Molecular cloning, functional expression, and gene silencing of two Drosophila receptors for the Drosophila neuropeptide pyrokinin-2, Biochem. Biophys. Res. Commun. 309 (2003) 485494. doi:10.1016/j.bbrc.2003.08.022.

[154] K. Egerod, E. Reynisson, F. Hauser, M. Williamson, G. Cazzamali, C.J.. Grimmelikhuijzen, Molecular identification of the first insect proctolin receptor, Biochem. Biophys. Res. Commun. 306 (2003) 437-442. doi:10.1016/S0006-291X(03)00997-5.

[155] N. Yapici, Y.-J. Kim, C. Ribeiro, B.J. Dickson, A receptor that mediates the post-mating switch in Drosophila reproductive behaviour., Nature. 451 (2008) 33-7. doi:10.1038/nature06483.

[156] J. Poels, T. Van Loy, H.P. Vandersmissen, B. Van Hiel, S. Van Soest, R.J. Nachman, et al., Myoinhibiting peptides are the ancestral ligands of the promiscuous Drosophila sex peptide receptor., Cell. Mol. Life Sci. 67 (2010) 3511-22. doi:10.1007/s00018-010-0393-8.

[157] E.C. Johnson, O.T. Shafer, J.S. Trigg, J. Park, D.A. Schooley, J.A. Dow, et al., A novel diuretic hormone receptor in Drosophila: evidence for conservation of CGRP signaling., J. Exp. Biol. 208 (2005) 1239-46. doi:10.1242/jeb.01529.

[158] X. Chen, J. Peterson, R.J. Nachman, B. Ganetzky, Drosulfakinin activates CCKLR-17D1 and promotes larval locomotion and escape response in Drosophila., Fly (Austin). 6 (2012) 290-7. doi:10.4161/fly.21534.

[159] E.C. Johnson, Drosophila CG8422 encodes a functional diuretic hormone receptor, J. Exp. Biol. 207 (2004) 743-748. doi:10.1242/jeb.00818.

[160] C.E. Hector, C. a Bretz, Y. Zhao, E.C. Johnson, Functional differences between two CRFrelated diuretic hormone receptors in Drosophila., J. Exp. Biol. 212 (2009) 3142-7. doi:10.1242/jeb.033175.

[161] G. Cazzamali, F. Hauser, S. Kobberup, M. Williamson, C.J.. Grimmelikhuijzen, Molecular identification of a Drosophila $\mathrm{G}$ protein-coupled receptor specific for crustacean cardioactive 
peptide, Biochem. Biophys. Res. Commun. 303 (2003) 146-152. doi:10.1016/S0006291X(03)00302-4.

[162] A. Iversen, G. Cazzamali, M. Williamson, F. Hauser, C.J.. Grimmelikhuijzen, Molecular identification of the first insect ecdysis triggering hormone receptors, Biochem. Biophys. Res. Commun. 299 (2002) 924-931. doi:10.1016/S0006-291X(02)02798-5.

[163] S. Sudo, Y. Kuwabara, J.-I. Park, S.Y. Hsu, A.J.W. Hsueh, Heterodimeric fly glycoprotein hormone-alpha2 (GPA2) and glycoprotein hormone-beta5 (GPB5) activate fly leucine-rich repeat-containing $G$ protein-coupled receptor-1 (DLGR1) and stimulation of human thyrotropin receptors by chimeric fly GPA2 and human GPB5., Endocrinology. 146 (2005) 3596-604. doi:10.1210/en.2005-0317.

[164] J.C. Radford, S.A. Davies, J.A.T. Dow, Systematic G-protein-coupled receptor analysis in Drosophila melanogaster identifies a leucokinin receptor with novel roles., J. Biol. Chem. 277 (2002) 38810-7. doi:10.1074/jbc.M203694200.

[165] S.F. Garczynski, M.R. Brown, P. Shen, T.F. Murray, J.W. Crim, Characterization of a functional neuropeptide F receptor from Drosophila melanogaster., Peptides. 23 (2002) 77380 .

[166] S. Hyun, Y. Lee, S.-T. Hong, S. Bang, D. Paik, J. Kang, et al., Drosophila GPCR Han is a receptor for the circadian clock neuropeptide PDF., Neuron. 48 (2005) 267-78. doi:10.1016/j.neuron.2005.08.025.

[167] I. Mertens, A. Vandingenen, E.C. Johnson, O.T. Shafer, W. Li, J.S. Trigg, et al., PDF receptor signaling in Drosophila contributes to both circadian and geotactic behaviors., Neuron. 48 (2005) 213-9. doi:10.1016/j.neuron.2005.09.009.

[168] C.-W. Luo, E.M. Dewey, S. Sudo, J. Ewer, S.Y. Hsu, H.-W. Honegger, et al., Bursicon, the insect cuticle-hardening hormone, is a heterodimeric cystine knot protein that activates $\mathrm{G}$ protein-coupled receptor LGR2., Proc. Natl. Acad. Sci. U. S. A. 102 (2005) 2820-5. doi:10.1073/pnas.0409916102.

[169] T. Ida, T. Takahashi, H. Tominaga, T. Sato, K. Kume, M. Ozaki, et al., Identification of the novel bioactive peptides dRYamide-1 and dRYamide-2, ligands for a neuropeptide Y-like receptor in Drosophila., Biochem. Biophys. Res. Commun. 410 (2011) 872-7. doi:10.1016/j.bbrc.2011.06.081.

[170] I. Mertens, T. Meeusen, R. Huybrechts, A. De Loof, L. Schoofs, Characterization of the short neuropeptide F receptor from Drosophila melanogaster., Biochem. Biophys. Res. Commun. 297 (2002) 1140-8.

[171] L.M. Jørgensen, F. Hauser, G. Cazzamali, M. Williamson, C.J.P. Grimmelikhuijzen, Molecular identification of the first SIFamide receptor., Biochem. Biophys. Res. Commun. 340 (2006) 696-701. doi:10.1016/j.bbrc.2005.12.062.

[172] T.M. Kubiak, M.J. Larsen, K.J. Burton, C.A. Bannow, R.A. Martin, M.R. Zantello, et al., Cloning and functional expression of the first Drosophila melanogaster sulfakinin receptor DSK-R1., Biochem. Biophys. Res. Commun. 291 (2002) 313-20. doi:10.1006/bbrc.2002.6459.

[173] J. Poels, R.T. Birse, R.J. Nachman, J. Fichna, A. Janecka, J. Vanden Broeck, et al., Characterization and distribution of NKD, a receptor for Drosophila tachykinin-related peptide 6., Peptides. 30 (2009) 545-56. doi:10.1016/j.peptides.2008.10.012. 
[174] R.T. Birse, E.C. Johnson, P.H. Taghert, D.R. Nässel, Widely distributed Drosophila G-proteincoupled receptor (CG7887) is activated by endogenous tachykinin-related peptides., J. Neurobiol. 66 (2006) 33-46. doi:10.1002/neu.20189.

[175] T. Ida, T. Takahashi, H. Tominaga, T. Sato, K. Kume, K. Yoshizawa-Kumagaye, et al., Identification of the endogenous cysteine-rich peptide trissin, a ligand for an orphan $\mathrm{G}$ proteincoupled receptor in Drosophila., Biochem. Biophys. Res. Commun. 414 (2011) 44-8. doi:10.1016/j.bbrc.2011.09.018.

[176] P.G. Szekeres, Functional assays for identifying ligands at orphan $\mathrm{G}$ protein-coupled receptors., Receptors Channels. 8 (2002) 297-308. doi:10.1080/10606820214642.

[177] P. Thomas, T.G. Smart, HEK293 cell line: a vehicle for the expression of recombinant proteins., J. Pharmacol. Toxicol. Methods. 51 (2005) 187-200. doi:10.1016/j.vascn.2004.08.014.

[178] S.J. Dowell, A.J. Brown, Yeast assays for G protein-coupled receptors., Methods Mol. Biol. 552 (2009) 213-29. doi:10.1007/978-1-60327-317-6_15.

[179] J. Vanden Broeck, V. Vulsteke, R. Huybrechts, A. De Loof, Characterization of a cloned locust tyramine receptor cDNA by functional expression in permanently transformed Drosophila $\mathrm{S} 2$ cells, J. Neurochem. 64 (1995) 2387-2395.

[180] M.R. Lerner, Tools for investigating functional interactions between ligands and G-protein coupled receptors, Trends Neurosci. 17 (1994) 142-146.

[181] G. Feng, F. Hannan, V. Reale, Y.Y. Hon, C.T. Kousky, P.D. Evans, et al., Cloning and Functional Characterization Receptor from Drosophila melanogaster of a Novel Dopamine, J. Neurosci. 16 (1996) 3925-3933.

[182] A. Martínez-Torres, R. Miledi, Expression of Caenorhabditis elegans neurotransmitter receptors and ion channels in Xenopus oocytes., Proc. Natl. Acad. Sci. U. S. A. 103 (2006) 5120-4. doi:10.1073/pnas.0600739103.

[183] A. Wise, S.C. Jupe, S. Rees, The identification of ligands at orphan G-protein coupled receptors., Annu. Rev. Pharmacol. Toxicol. 44 (2004) 43-66. doi:10.1146/annurev.pharmtox.44.101802.121419.

[184] I. Mertens, A. Vandingenen, T. Meeusen, A. De Loof, L. Schoofs, Postgenomic characterization of G-protein-coupled receptors., Pharmacogenomics. 5 (2004) 657-72. doi:10.1517/14622416.5.6.657.

[185] S. Offermanns, M.I. Simon, G alpha 15 and $\mathrm{G}$ alpha 16 couple a wide variety of receptors to phospholipase C., J. Biol. Chem. 270 (1995) 15175-15180. doi:10.1074/jbc.270.25.15175.

[186] B.R. Conklin, Z. Farfel, K.D. Lustig, D. Julius, H.R. Bourne, Substitution of three amino acids switches receptor specificity of Gq alpha to that of Gi alpha., Nature. 363 (1993) 274-276. doi:10.1038/363274a0.

[187] D.C. Prasher, R.O. McCann, M. Longiaru, M.J. Cormier, Sequence comparisons of complementary DNAs encoding aequorin isotypes., Biochemistry. 26 (1987) 1326-1332. 
[188] D. Gabriel, M. Vernier, M.J. Pfeifer, B. Dasen, L. Tenaillon, R. Bouhelal, High throughput screening technologies for direct cyclic AMP measurement., Assay Drug Dev. Technol. 1 (2003) 291-303. doi:10.1089/15406580360545107.

[189] C. Williams, cAMP detection methods in HTS: selecting the best from the rest., Nat. Rev. Drug Discov. 3 (2004) 125-35. doi:10.1038/nrd1306.

[190] R.M. Eglen, Functional G protein-coupled receptor assays for primary and secondary screening., Comb. Chem. High Throughput Screen. 8 (2005) 311-8.

[191] E.C. Johnson, L.M. Bohn, L.S. Barak, R.T. Birse, D.R. Nässel, M.G. Caron, et al., Identification of Drosophila neuropeptide receptors by $\mathrm{G}$ protein-coupled receptors-betaarrestin2 interactions., J. Biol. Chem. 278 (2003) 52172-8. doi:10.1074/jbc.M306756200.

[192] R. Zhang, X. Xie, Tools for GPCR drug discovery., Acta Pharmacol. Sin. 33 (2012) 372-84. doi:10.1038/aps.2011.173.

[193] C. Doucette, K. Vedvik, E. Koepnick, A. Bergsma, B. Thomson, T.C. Turek-Etienne, Kappa opioid receptor screen with the Tango beta-arrestin recruitment technology and characterization of hits with second-messenger assays., J. Biomol. Screen. 14 (2009) 381-94. doi: $10.1177 / 1087057109333974$.

[194] H. Yin, A. Chu, W. Li, B. Wang, F. Shelton, F. Otero, et al., Lipid G protein-coupled receptor ligand identification using beta-arrestin PathHunter assay., J. Biol. Chem. 284 (2009) 1232838. doi:10.1074/jbc.M806516200.

[195] X.J. Li, W. Wolfgang, Y.N. Wu, R.A. North, M. Forte, Cloning, heterologous expression and developmental regulation of a Drosophila receptor for tachykinin-like peptides., EMBO J. 10 (1991) 3221-9.

[196] M.D. Adams, The Genome Sequence of Drosophila melanogaster, Science. 287 (2000) 21852195. doi:10.1126/science.287.5461.2185.

[197] R.S. Hewes, P.H. Taghert, Neuropeptides and neuropeptide receptors in the Drosophila melanogaster genome., Genome Res. 11 (2001) 1126-1142. doi:10.1101/gr.169901.

[198] C. Wegener, A. Gorbashov, Molecular evolution of neuropeptides in the genus Drosophila., Genome Biol. 9 (2008) R131. doi:10.1186/gb-2008-9-8-r131.

[199] E. Clynen, A. Reumer, G. Baggerman, I. Mertens, L. Schoofs, Neuropeptide Biology in Drosophila, Adv. Exp. Med. Biol. 692 (2010) 192-210.

[200] S.J. Husson, A. Reumer, L. Temmerman, W. De Haes, L. Schoofs, I. Mertens, et al., Worm peptidomics, EuPA Open Proteomics. 3 (2014) 280-290. doi:10.1016/j.euprot.2014.04.005.

[201] J.M. Atienza, N. Yu, X. Wang, X. Xu, Y. Abassi, Label-free and real-time cell-based kinase assay for screening selective and potent receptor tyrosine kinase inhibitors using microelectronic sensor array., J. Biomol. Screen. 11 (2006) 634-43. doi:10.1177/1087057106289334.

[202] K.F. Rewitz, N. Yamanaka, L.I. Gilbert, M.B. O'Connor, The insect neuropeptide PTTH activates receptor tyrosine kinase torso to initiate metamorphosis., Science. 326 (2009) 1403-5. doi:10.1126/science.1176450. 
[203] E.H. Seeley, R.M. Caprioli, Molecular imaging of proteins in tissues by mass spectrometry., Proc. Natl. Acad. Sci. U. S. A. 105 (2008) 18126-31. doi:10.1073/pnas.0801374105.

[204] D.R. Nässel, P. Ekström, Detection of neuropeptides by immunocytochemistry., Methods Mol. Biol. 72 (1997) 71-101. doi:10.1385/0-89603-394-5:71.

[205] U. Homberg, Neurotransmitters and Neuropeptides in the Brain of the locust, Microsc. Res. Tech. 56 (2002) 189-209.

[206] O. Koizumi, N. Sato, C. Goto, Chemical anatomy of hydra nervous system using antibodies against hydra neuropeptides : a review, (2004) 41-47.

[207] D.R. Nässel, U. Homberg, Neuropeptides in interneurons of the insect brain., Cell Tissue Res. 326 (2006) 1-24. doi:10.1007/s00441-006-0210-8.

[208] F. Cebrià, Organization of the nervous system in the model planarian Schmidtea mediterranea: an immunocytochemical study., Neurosci. Res. 61 (2008) 375-84.

doi:10.1016/j.neures.2008.04.005.

[209] P. McVeigh, G.R. Mair, L. Atkinson, P. Ladurner, M. Zamanian, E. Novozhilova, et al., Discovery of multiple neuropeptide families in the phylum Platyhelminthes., Int. J. Parasitol. 39 (2009) 1243-52. doi:10.1016/j.ijpara.2009.03.005.

[210] R.W. Burry, Specificity Controls for Immunocytochemical Methods, J. Histochem. Cytochem. 48 (2000) 163-165. doi:10.1177/002215540004800201.

[211] M. Aquino de Muro, Probe Design, Production, and Applications, in: Mol. Biomethods Handb., 2008: pp. 41-53.

[212] J.D. Plautz, R.N. Day, G.M. Dailey, S.B. Welsh, J.C. Hall, S. Halpain, et al., Drosophila melanogaster, 173 (1996) 83-87.

[213] G.H. Patterson, A new harvest of fluorescent proteins., Nat. Biotechnol. 22 (2004) 1524-5. doi:10.1038/nbt1204-1524.

[214] G.-J. Kremers, S.G. Gilbert, P.J. Cranfill, M.W. Davidson, D.W. Piston, Fluorescent proteins at a glance, J. Cell Sci. 124 (2011) 2676-2676. doi:10.1242/jcs.095059.

[215] T. Boulin, J.F. Etchberger, O. Hobert, Reporter gene fusions., WormBook. (2006) 1-23. doi:10.1895/wormbook.1.106.1.

[216] L.A. Berkowitz, A.L. Knight, G. a Caldwell, K.A. Caldwell, Generation of stable transgenic $C$. elegans using microinjection., J. Vis. Exp. (2008) 2-5. doi:10.3791/833.

[217] A. Fire, S.W. Harrison, D. Dixon, A modular set of lacZ fusion vectors for studying gene expression in Caenorhabditis elegans, 93 (1990) 189-198.

[218] D.M. Miller, N.S. Desai, D.C. Hardin, D.W. Piston, G.H. Patterson, J. Fleenor, et al., Twocolor GFP expression system for C. elegans., Biotechniques. 26 (1999) 914-8, 920-1.

[219] O. Hobert, PCR fusion-based approach to create reporter gene constructs for expressino analysis in transgenic C. elegans, Biotechniques. 32 (2002) 4-6. 
[220] A.H. Brand, N. Perrimon, Targeted gene expression as a means of altering cell fates and generating dominant phenotypes., Development. 118 (1993) 401-15.

[221] J.B. Duffy, GAL4 system in Drosophila: a fly geneticist's Swiss army knife., Genes. New York NY 2000. 34 (2002) 1-15.

[222] M.M. Gessel, J.L. Norris, R.M. Caprioli, MALDI imaging mass spectrometry: Spatial molecular analysis to enable a new age of discovery., J. Proteomics. 107C (2014) 71-82. doi:10.1016/j.jprot.2014.03.021.

[223] Q. Yu, C. OuYang, Z. Liang, L. Li, Mass spectrometric characterization of the crustacean neuropeptidome, EuPA Open Proteomics. 3 (2014) 152-170.

doi:10.1016/j.euprot.2014.02.015.

[224] S.S. DeKeyser, K.K. Kutz-Naber, J.J. Schmidt, G.A. Barrett-Wilt, L. Li, Imaging mass spectrometry of neuropeptides in decapod crustacean neuronal tissues., J. Proteome Res. 6 (2007) 1782-91. doi:10.1021/pr060603v.

[225] R. Chen, L. Hui, R.M. Sturm, L. Li, Three dimensional mapping of neuropeptides and lipids in crustacean brain by mass spectral imaging., J. Am. Soc. Mass Spectrom. 20 (2009) 1068-77. doi:10.1016/j.jasms.2009.01.017.

[226] H. Ye, L. Hui, K. Kellersberger, L. Li, Mapping of neuropeptides in the crustacean stomatogastric nervous system by imaging mass spectrometry., J. Am. Soc. Mass Spectrom. 24 (2013) 134-47. doi:10.1007/s13361-012-0502-z.

[227] Z. Herbert, S. Rauser, L. Williams, N. Kapan, M. Güntner, A. Walch, et al., Developmental expression of neuromodulators in the central complex of the grasshopper Schistocerca gregaria., J. Morphol. 271 (2010) 1509-26. doi:10.1002/jmor.10895.

[228] P.D.E.M. Verhaert, M.W.H. Pinkse, K. Strupat, M.C.P. Conaway, Imaging of similar mass neuropeptides in neuronal tissue by enhanced resolution MALDI MS with an ion trap Orbitrap hybrid instrument., Methods Mol. Biol. 656 (2010) 433-49. doi:10.1007/978-160761-746-4_25.

[229] M. Pratavieira, A.R. da Silva Menegasso, A.M.C. Garcia, D.S. Dos Santos, P.C. Gomes, O. Malaspina, et al., MALDI imaging analysis of neuropeptides in the Africanized honeybee (Apis mellifera) brain: effect of ontogeny., J. Proteome Res. 13 (2014) 3054-64. doi:10.1021/pr500224b.

[230] J.Y. Yew, K.K. Kutz, S. Dikler, L. Messinger, L. Li, A.O. Stretton, Mass spectrometric map of neuropeptide expression in Ascaris suum., J. Comp. Neurol. 488 (2005) 396-413. doi:10.1002/cne.20587.

[231] P. Chansela, N. Goto-Inoue, N. Zaima, M. Sroyraya, P. Sobhon, M. Setou, Visualization of neuropeptides in paraffin-embedded tissue sections of the central nervous system in the decapod crustacean, Penaeus monodon, by imaging mass spectrometry., Peptides. 34 (2012) 10-8. doi:10.1016/j.peptides.2011.03.021.

[232] Y. Park, Y.-J. Kim, M.E. Adams, Identification of G protein-coupled receptors for Drosophila PRXamide peptides, CCAP, corazonin, and AKH supports a theory of ligand-receptor coevolution., Proc. Natl. Acad. Sci. U. S. A. 99 (2002) 11423-8. doi:10.1073/pnas.162276199. 
[233] G. Lee, J.H. Park, Hemolymph sugar homeostasis and starvation-induced hyperactivity affected by genetic manipulations of the adipokinetic hormone-encoding gene in Drosophila melanogaster., Genetics. 167 (2004) 311-23.

[234] S. Dillen, S. Zels, H. Verlinden, J. Spit, P. Van Wielendaele, J. Vanden Broeck, Functional characterization of the short neuropeptide F receptor in the desert locust, Schistocerca gregaria., PLoS One. 8 (2013) e53604. doi:10.1371/journal.pone.0053604. 